\title{
A Tellegen Abszorpciós Skála részletes pszichometriai elemzése
}

\author{
RÓZSA SÁNDOR ${ }^{1}$ - HUPUCZI ERNŐ² - MARTIN LÁSZLÓ ${ }^{3}$ \\ BIRKÁS BÉLA ${ }^{2}$ - HARTUNG ISTVÁN² - HARGITAI RITA ${ }^{4}$ - \\ VARGA JÓZSEF ${ }^{1}$ - LÁNG ANDRÁS ${ }^{5}$ - \\ TIRINGER ISTVÁN ${ }^{2}$ - KÁLLAI JÁNOS²*
}

\author{
${ }^{1}$ Department of Psychiatry, Washington University School of Medicine, St. Louis, USA \\ ${ }^{2}$ Pécsi Tudományegyetem, Magatartástudományi Intézet, Pécs \\ ${ }^{3}$ Kaposvári Egyetem, Pedagógiai és Pszichológiai Tanszék, Kaposvár \\ ${ }^{4}$ Pázmány Péter Katolikus Egyetem, Budapest
}

${ }^{5}$ Pécsi Tudományegyetem, Bölcsészettudományi Kar, Pszichológiai Intézet, Pécs

(Beérkezett: 2018. április 3.; elfogadva: 2019. január 14.)

Háttér: Az abszorpció mérésére a leggyakrabban a 34 tételes Tellegen Abszorpció Skálát alkalmazzák. Az önjellemző mérőeszköz széles körú elterjedtségének ellenére viszonylag csekély azon közlemények száma, amelyek a mérőeszköz részletes pszichometriai jellemzőinek feltárására (pl. faktorszerkezet, skálák belső konzisztenciája) irányulnak. Célkitüzés: Vizsgálatunk fő kérdésfeltevése az, hogy az abszorpció mennyire tekinthető önálló, látens dimenziónak, bontható-e további alfaktorokra, illetve az alfaktorokból képzett skálák milyen megbízhatóságúak, és mennyivel árnyalják a főskálán szerzett eredményeket. Kíváncsiak voltunk arra is, hogy az 5-fokozatú Likert-skálás és a dichotóm válaszformátumok mennyire befolyásolják a mérőeszköz strukturális validitását és skáláinak belső homogenitását. Módszerek: Az 5-fokozatú Likert-skálás válaszformátumú TAS-t összesen 1935 hallgató töltötte ki, a dichotóm válaszformátumút pedig 399 személy. A mérőeszköz strukturális validitását feltáró és megerősítő faktorelemzések (pl. egyfaktoros modell, modell másodrendú faktorral, bifaktoros modell), valamint parallel-elemzés segítségével vizsgáltuk. A kapott alksálák reliabilitását nemcsak a hagyományos módon (Cronbachalfa), hanem az általános faktor kontrollálása mellett is kiszámoltuk (hierarchikus omega, magyarázott közös variancia). Eredmények: Az eredeti 34 tételes változatok (Likert-skálás és dichotóm válaszformátumú), illetve a feltáró faktorelemzések eredményei alapján rövidített 23 tételes változat megerősítő faktorelemzései során egyértelmúen a bifaktoros elrendezések adták a legjobb illeszkedési mutatókat és az általános faktor (főskála) megbízhatósága kiváló volt. Ezzel szemben az alkálák reliabilitása, az általános faktor kontrollálása mellett, már nem volt megfelelő. Az alkalmazható faktorok számának meghatározására a parallel-elemzés kiváló becslést adott, mind az 5-fokozatú Likert-skálás, mind a dichotóm válaszformátum esetében az egydimenziós szerkezetet valószínúsítette. Következtetések: A kapott eredményeink egyrészről alátámasztják azt, hogy az abszorpció egy

\footnotetext{
* Levelező szerző: Prof. Dr. Kállai János, Pécsi Tudományegyetem, Magatartástudományi Intézet, 7624 Pécs, Szigeti út 12. E-mail: janos.kallai@aok.pte.hu
} 
látens pszichológiai változónak tekinthetó, másrészről pedig a hagyományos statisztikai módszerek korlátaira hívják fel a figyelmet, és a többféle módszer kombinált alkalmazásának hatékonyságát támasztják alá.

Kulcsszavak: abszorpció, Tellegen Abszorpció Skála, megerősítő és feltáró faktorelemzés, parallel-elemzés, bifaktoros modell, modell-alapú reliabilitás, hierarchikus omega

\section{Bevezetés}

Az abszorpciós képesség, az exteroceptív és interoceptív ingerekre vonatkozó fokozott érzékenység, felfokozott személyes érzelmekre hagyatkozó részvétel, amely szerepet játszik a múvészi kifejező- és befogadóképességben (Kane, Lind, Polasek, \& Hendric, 2017), a hipnózis iránti fogékonyságban (Jamieson, 2005; Kirsch, 1997; Tellegen \& Atkinson, 1974), a szokatlan - esetenként mágikus, spirituális - élmények iránti befogadókészségben (Witthöft, Rist, \& Bailer, 2008), és a genetikai prediszpozícók kibontakoztatásában (Bachner-Melman és mtsai, 2005; Székely és mtsai, 2010). Előadómúvészeknél elősegíti a szerep által megkívánt érzések, helyzetek által támasztott követelményekbe való belemerülést, az előadott mú képzeleti megjelenítését, a figyelem összpontosítást, az interakcióban résztvevő felek fiziológiai együttmozgását, természeti jelenségek, emberi történések mély átélését, az érzelmi és kognitív rezonanciát (Carleton, Abrams, \& Asmundon, 2010; Roche \& McCorky, 1990).

Pácienseknél befolyásolja a szomatikus vagy mentális tünetek megjelenésének intenzitását (Rosen és mtsai, 2017; Simor, Köteles, \& Bódizs, 2011; Witthöft, Rist, \& Bailer, 2008). Az abszorpciós képesség jelentősen erősödik bipoláris pszichózisok és a szkizofrénia spektrumba tartozó mentális betegségek kibontakozása során, fokozza a hallucinációk és a téveszmék intenzitását, továbbá növeli a disszociációra való hajlamot, amelynek következményeként a kényszergondolatok és kényszercselekvések is felerősödnek (Soffer-Dudek, Lassri, Soffer-Dudek, \& Shahar, 2015).

Az abszorpció két egymásra épülő értelmezési folyamatot tartalmaz, amely az intero- és az exteroceptív ingerek feldolgozási és összekapcsolási módját írja le. Egyedi jellegzetesség, amely a külsó belsővé, a belső külsővé válásának, lényegében a szelf múködésmódjának, az énhatárainak, a feldolgozási folyamatok tudatossági szintjét, a realitáskontroll mértékét mutatja meg (Kihlstrom, 2012). Minden ember személyes élettapasztalata alapján értékeli az intero- vagy exteroceptív ingereket és ezek kapcsolata alapján alakítja ki az élményeit. A helyzetben való személyes részvétel mértékétől függően nyitott az események multimodális szenzoros komponensei iránt. A személyes nyitottságot a határozott érzelmi jelenlét (presence) képviseli, amely viszonylag laza mentális kontroll mellett lehetóvé teszi az inte- 
roceptív és az exteroceptív ingerek közvetlen összekapcsolódását. Ennek az affiliatív, inkorporációs folyamatnak az eredményeként nyilvánul meg (emergence) a helyzetre, feladatra, eseményre vonatkozó személyes élmény, amely a helyzetbe való belemerülés révén az énhatáraitól függetlenül a szociális és a fizikai környezet ökonómikus szereplőjévé teszi a személyt (Kihlstrom, Glisky, Peterson, Harvey, \& Rose, 1991). Ez az élményvezérelt észlelési gyakorlat növeli az automatikus válaszok gyorsaságát, de jelentős számú - és a kiváltó hatás szempontjából konfliktusban lévő - események esetén, rontja az automatikus válasz ökológiai validitását.

Simor és munkatársai (2011) „Elmerülés az élményben” címú munkájukban Hartman (1991) mentális állapotok és funkciók közötti határok (boundaries in mind) meghatározását felidézve felvetik, hogy az abszorpciós személyiségvonás a kreatív problémamegoldó gondolkodás és az alkotásra összpontosító életvezetés fontos részeként, feszültségcsökkentő mechanizmusként is múködik az énhatárok bizonytalanságával küzdő személyeknél. Magunk is látunk esélyt arra, hogy az abszorpció hatókörére vonatkozó modellünket a szelf-határok és az énvédelem irányába kiterjesszük. Ezen megállapítások alapján az abszorpciós képességnek a szociális adaptációban, és a mentális egészség fenntartásában betöltött szerepét vizsgálva jogosan vethetjük fel azt a kérdést, hogy ennek a viszonylag gyenge kognitív kontrollt magában rejtő képességnek milyen szerepe van a konfliktushelyzetek megoldásában, továbbá a személy milyen módon védekezik az ôt elárasztó ingerek világában. Hogyan őrzi meg vagy állítja vissza adaptációs lehetőségeit? Úgy látjuk, hogy a szelf domináns múködésmódja ebben a helyzetben nem a viselkedés és a mentális múveletek tudatossági szintjének növekedésén keresztül valósul meg, hanem az élmények egy kiemelt területére való fokozott koncentrációval, a valóság személyes élettörténeti elemekkel színezett adott területére való beszúküléssel. Ez esetben a személyes élettörténet által hitelesített élmény, kongruens értelmezési modellként lehetővé teszi az átlényegülést (self-fulfilment, transsubstantiation), az affektív köntösben megjelenó élettapasztalat a megértés közvetlen eszközeként jelenik meg. Azaz katartikus lesz, az átélés a megértés eszközévé válik.

\subsection{A Tellegen Abszorpció Skála (TAS) kidolgozása és a skálával végzett pszichometriai elemzések áttekintése}

Tellegen az 1970-es években a hipnotikus fogékonyság kérdőíves vizsgálata során, 11 homogén skála faktorelemzése alapján azonosította a már jól ismert Neuroticizmus $(\mathrm{N})$ és Extraverzió (E) átfogó dimenziók mellett az Abszorpcióra való nyitottságot (Tellegen \& Atkinson, 1974). A későbbiekben McCrae és Costa (1985) erre a modellre, mint korai háromfaktoros 
struktúrára (NEO) hivatkoznak, amelyet néhány évvel később ettől függetlenül ook is megkaptak. A vizsgálataik alapján az Abszorpció és a Nyitottság (O) skálák közötti korrelációk magasak $(r=0,55$ és $r=0,56)$, illetve mások még ennél is szorosabb együttjárásokat kaptak: $r=0,68$ (Glisky és mtsai, 1991); $r=0,62$ (Radtke \& Stam, 1991); $r=0,64$ (Wild, Kuiken, \& Schopflocher, 1995). Az abszorpció és az átfogó személyiségmodellek összevetésekor érdemes megemlíteni, hogy az abszorpció a Cloninger-féle Temperamentum és Karakter modell Transzcendencia-élmény dimenziójával is szoros együttjárást mutat: $r=0,64$ (Laidlow, Dwivedi, Naito, \& Gruzelier, 2005).

Tellegen az abszorpciót méró tételek részletes tartalmi- és faktorelemzésével, valamint a tételek többszöri cseréjével és finomításával alakította ki a kutatók körében jól ismert 34 tételes Abszorpció Skálát, amelynek tételeit igaz - nem igaz válaszformátum mentén kell megítélnie a kitöltőnek (Tellegen, 1981; Tellegen \& Waller, 2008). A kérdőív faktorszerkezetéről egy 1992-ben írott és máig kiadatlan kéziratban számolt be a szerző, amelynek empirikus hátterét 2000 fős minnesotai lakossági minta szolgáltatta. Az elemzések alapján az alábbi 6 dimenziót különböztette meg: A lebilincselő élményekre való fogékonyság; Szineztézia; Kiterjesztett kogníció; A tevékenységekben való teljes elmerülés; Az emlékek élénksége; Kiterjesztett tudatosság (Simor és mtsai, 2011; Tellegen, 1992).

A 34 tételes kérdőív önálló mérőeszközként, valamint a Tellegen által kidolgozott és több mint 10 éven keresztül fejlesztett Többdimenziós Személyiség Kérdőív (Multidimensional Personality Questionnaire, MPQ; Tellegen \& Waller, 2008) részeként is megjelenik. Az átfogó személyiségkérdőív első változataiban az abszorpció kitüntetett helyet foglalt el, mivel az elsődleges és a másodlagos faktorok között is szerepel. A kérdőív 11 elsődleges faktort tartalmaz (Jóllét, Társas befolyás, Teljesítmény, Társas közelség, Stresszreakció, Agresszió, Elidegenedés, Kontroll, Ártalomkerülés, Tradicionalizmus, Abszorpció), amelyek további 4 másodlagos dimenzióba szerveződnek: Pozitív érzelmek, Negatív érzelmek, Korlátozás és Abszorpció. A későbbi tudományos publikációkban az abszorpció már csak az elsődleges faktorok között szerepel. Az abszorpció másodlagos dimenzióvá válását az a tény támogatta, hogy ez az elsődleges faktor sem a pozitív és negatív érzelmekkel, sem a korlátozással nem korrelált jelentósen. A késóbbiekben a pozitív érzelmek személyes és társas komponensekre történő felosztásával ez a probléma valamelyest megoldódott, mivel az Abszorpció a Jóllét, a Társas befolyás és a Teljesítmény alkotta faktorba már besorolható volt (Tellegen \& Waller, 2008). Az MPQ kérdőíven belül az abszorpció skála többszöri átdolgozásra is került, és az MPQ végleges változatában a skálának két alskálája van: Érző (Sentient), valamint a Képzeletbeli és módosult tudatállapotokra való hajlamosság (Prone to imaginitive and altered states). A 276 tételes MPQ kérdőívnek van 155 tételból álló rövidített változata is, melyben az abszorpciót 12 tétel méri (Patrick \& Kramer, 2017). 
A pszichológiai jellegú kutatásokban általában a TAS önálló változatát alkalmazzák. A szakirodalmi keresók (pl. PubMed, OVID) alapján a mérőeszközt számos nyelvre lefordították (pl. cseh, dán, francia, héber, koreai, német, spanyol), ennek ellenére a mérőeszközzel végzett pszichometriai jellegú tanulmányok száma kevés, többnyire a skálát, mint egydimenziós méróeszköz használják. A széleskörú pszichometriai vizsgálatokat elsősorban az gátolja, hogy az MPQ méróeszköz hivatalos forgalmazója, a University of Minnesota Press a skálát szerzőjogilag levédte, és bár ad engedélyt a kutatási célú felhasználásra, a tételek változtatásához és új skálák vagy alskálák létrehozásához nem járul hozzá.

A szakirodalmi keresés során viszonylag kevés olyan tanulmányt azonosítottunk, amelyben a 34 tételes mérőeszközt nagy vizsgálati mintán és részletes pszichometriai elemzésnek vetették alá (pl. belső konzisztencia és faktorszerkezet-vizsgálat, konstruktumvaliditás), többnyire a hipnábilitás bejósló prediktoraként alkalmazták, és más hasonló skálákkal vagy átfogó személyiségmodellekkel vetették össze.

A mérőeszköz első átfogó elemzéseit Glisky és munkatársai (1991) adták, akik több vizsgálati mintát és kutatási elrendezést felhasználva az abszorpció, a nyitottság a tapasztalatokra és a hipnotikus fogékonyság kapcsolatrendszerét vizsgálták. Ennek keretében azonban a TAS tételeinek részletes vizsgálatára, faktorelemzésére nem került sor. A kutatócsoport a TAS tartalmi alapokon nyugvó 9 kategóriáját, az ötfaktoros NEO-PI (Costa \& McCrae, 1985) méróeszköz 5 nyitottság a tapasztalatra alskáláját, valamint a Coanféle Experience Inventory (Coan, 1972) 7 skáláját együttesen elemezték, vizsgálva azt, hogy milyen átfogó dimenziókba rendezhetók a skálák. A fentiekhez hasonlóan több kutatócsoport is a TAS és más kérdőívek kapcsolatrendszerét vizsgálták úgy, hogy a skálán elért eredményeken faktorelemzést hajtottak végre. O'Grady (1980) az abszorpciót többek között a Spielberger-féle Állapot és Vonásszorongás Kérdőívvel (Spielberger, Corsucrh, \& Lushenre, 1970), a Marlowe-Crowne-féle Szociális Kívánatosság Skálával (Crowne \& Marlowe, 1964) és az Adorno-féle F-skálával (Adorno, Frendkel-Brunswik, Levinson, \& Sanford, 1950) összevetve elemezte. Lyons és Crawford (1997) a hipnotikus fogékonyságot meghatározó figyelmi folyamatokat és az idegrendszeri aktivációt vizsgálta, és ennek keretében több mérőeszköz skáláin végeztek faktorelemzést: pl. Eysenck-féle Személyiség Kérdőív (Eysenck \& Eysenck, 1975), Stanford Hipnotikus Fogékonysági Skála (Weitzenhoffer \& Hilgard, 1962), Érzelmi Intenzitás Skála (Larsen, Diener, \& Emmons, 1986). Crawford (1982) korábbi vizsgálatában a hipnábilitás, a nappali álmodozás, az élénk képzeleti aktivitás és az abszorpció kapcsolatrendszerének vizsgálata során alkalmazott faktorelemzést.

Jamieson (2005) a TAS tételeit elsóként 5-fokozatúra alakította, majd a faktorszerkezetet főkomponens- és főtengelyelemzéssel vizsgálta. A főkom- 
ponens-elemzés 12 egynél nagyobb sajátértékú komponenst adott, úgy, hogy az első komponens sajátértéke kiugróan magas volt (9), a rákövetkező komponensek már csak 2 és ez alatti értékkel rendelkeztek. Annak ellenére, hogy az első komponens kiugróan magas értékkel rendelkezett, a komponens által magyarázott variancia csak a tételek összvarianciájának a 25,5\%át magyarázták. Ez az eredmény egyrészról megfeleltethető annak a kritikai elképzelésnek, amit Council és munkatársai (1986) fogalmaztak meg az abszorpcióról, mint vonásról és a TAS feltételezett mérési modelljéről. Véleményük szerint az abszorpció nem egy látens pszichológiai változó, sokkal inkább egy olyan gyújtőkosár, amelybe olyan tételek és tételcsoportok kerültek a hipnotikus fogékonyság mérésének kérdőíves tesztfejlesztése során, amelyek nem illeszkedtek más nagyobb dimenzióba: pl. extraverzió vagy neuroticizmus. Másrészról jelezheti azt is, hogy a TAS többdimenziós mérőeszköz. Jamieson (2005) ennek megfelelően főtengelyelemzéssel és ferde faktorforgatással, valamint a faktorokon végzett ismételt főkomponenselemzéssel olyan 5-faktoros struktúrát alakított ki, ahol az 5 dimenzió egy további magasabb rendú másodlagos faktorba szerveződik. A faktorszerkezet tisztítása során a kevéssé illeszkedő tételeket törölte, így egy 25 tételes TAS kérdőívet is elóállított, amely az alábbi skálákból állt (zárójelben az eredeti 34 tételes kérdőív sorszámai): Szinesztézia (10., 17., 27., 33.), Módosult tudatállapot (5., 8., 9., 11.), A természet szépségében való elmerülés (6., 15., 16., 23., 34.), A képzeletbe történő elmerülés (3., 7., 18., 19., 20., 21., 22., 25., 32.), Extraszenzoriális percepció (14., 28., 31.). Bár az 5 alskála mindegyike szignifikáns, pozitív irányú együttjárást adott a hipnotikus fogékonyság dichotomizált értékével, de a regresszió elemzések alapján az alskálák a másodlagos abszorpció dimenzió mellett nem rendelkeztek szignifikáns magyarázóeróvel.

Carleton és munkatársai (2010) a Tellegen Abszorpció Skála és a Disszociatív Élmények Skála tételeinek faktorszerkezetét együttesen és külön is vizsgálták. A 34 tételes és 5-fokozatú válaszformátumú TAS esetében a feltáró faktorelemzés során két faktort valószínúsítettek, amelyek az összvariancia 40\%-át magyarázták. A faktorokat alkotó tételek közül azonban sok meglehetôsen gyenge faktorsúlyt adott, vagy a másik faktorral is jelentős kapcsolatot, kereszttöltést mutatott. A kutatók végül a két mérőeszköz egyesített és szelektált tételeiből alkották meg azt a 15 tételes Figyelmi Forrás Allokáció Kérdőívet, amely a következő 3 dimenziót ragadja meg: abszorpció, disszociatív amnézia, figyelmi disszociáció.

Ritz és Dahme (1995) 252 fós egyetemi hallgatói mintán a 34 tételes igaz - nem igaz válaszformátumú TAS faktorszerkezetét és validitását vizsgálták. A feltáró faktorelemzés eredménye alapján a TAS leginkább egydimenziós szerkezettel jellemezhetó. 
Simor és munkatásai (2011) 576 fós hazai egyetemista mintán megerősítő faktorelemzéssel a dichotóm válaszformátumú TAS eredeti egy- és hatdimenziós faktorszerkezetet tesztelték. Mind az egydimenziós, mind a két hatdimenziós faktorszerkezet (6 elsődleges dimenzióval, illetve másodrendú dimenzióval kiegészítve) elfogadható illeszkedési mutatókat adott. Bár a legjobb illeszkedési mutatókkal a 6 elsődleges dimenzióra épüló modell rendelkezett, mérlegelve az alskálák megbízhatóságát a szerzők inkább a TAS összpontszámának használatát javasolják az abszorpció mérésére.

Bár a mérőeszközt elsődlegesen hipnóziskutatásokban használják, ennek ellenére az utóbbi időben az abszorpciót más terültek mérésére is kiterjesztették: pl. zenei élmény (Sandstrom \& Russo, 2013; Szabó, 2015), sport (Koehn és mtsai, 2017). Ezekben a kutatásokban gyakran a Tellegen Abszorpció Skála tételeit kiindulásként használják, és az adott terület jellemzőinek megfelelően fogalmazzák át.

A TAS-t Varga Katalin fordította magyarra és kezdetekben hazánkban is elsősorban hipnóziskutatásokban alkalmazták (pl. Szabó, 1989; Varga, 2004). A későbbiekben azonban olyan személyiségpszichológiai területekre is kiterjesztették a TAS használatát, ahol az élményekbe történő bevonódás mértékét igyekeztek megragadni: pl. poszttraumás növekedés (Kulcsár, Rózsa, \& Reinhardt, 2006), tünetképzés (Simor és mtsai, 2011), zenei élmény (Szabó, 2015; Székely, 2016), szerepjáték (Nagy, 2016), szexualitás (Horváth, 2016), nappali álmodozás (Sándor, 2017).

\subsection{Tanulmányunk célkitüzése}

Tanulmányunk középpontjában a Tellegen Abszorpciós Skála (TAS) részletes pszichometriai vizsgálata áll. Nem titkolt szándékunk, hogy az elemzéseink megválasztásának szempontjait és a kapott eredmények értelmezését, a módszertani problémákat gondosan körbejárva, lépésról-lépésre igyekszünk bemutatni, segítve ezzel a hazai tesztadaptációs kutatásokat. Az elemzéseink során több olyan eljárást is szemléltetünk, amelyek a jövőben az adaptációs kutatások fontos részét képezhetik.

Elemzéseink az 5-fokozatú válaszformátumú TAS mellett az igaz - nem igaz válaszalternativást használó változatra is kiterjednek, szemléltetve ezzel azt, hogy a válaszformátumok milyen hatással vannak egy mérőeszköz pszichometriai mutatóira és az elemzési lehetőségekre. Jól ismert tény, hogy a dichotóm válaszformátumú kérdőíves adatok elemzése többnyire speciális eljárást igényel, és a kevés tételból képzett alskálák alacsony varianciája gyakran nem megfelelő az alskálák megbízható értékeléséhez és értelmezéséhez. 
A mérőeszköz strukturális validitását feltáró és megerősítő faktorelemzések segítségével vizsgáljuk. Fő kérdésünk az, hogy az abszorpció mennyire tekinthető önálló, látens dimenziónak, bontható-e további alfaktorokra, illetve az alfaktorokból képzett skálák milyen megbízhatóságúak, és mennyivel árnyalják a főskálán szerzett eredményeket.

Tanulmányunk a már korábban publikált hazai eredményeket (Simor és mtsai, 2011) több ponton is kiegészíti. Kutatásunkban a dichotóm és az 5-fokozatú Likert-skálás változatot egyaránt vizsgáljuk, így lehetőségünk nyílik választ adni arra, hogy az eredeti dichotóm válaszformátumú változat esetében az alskálák gyenge belső konzisztenciáját a tételek alacsony varianciája okozza-e. Mindezek mellett a dichotóm válaszformátumú TAS esetében mintánkat elsődlegesen nem egyetemi hallgatók alkották, és az elemzéseinket bifaktoros megerősítő faktorelemzésekre és parallel-elemzésekre is kiterjesztettük.

Jelen vizsgálatunkat azért is érezzük fontosnak, mert a Jamieson (2005) által 5-fokozatú válaszformátumra alakított TAS változatot eddig hazánkban még nem elemezték, illetve nemzetközi szinten sem vizsgálták még hozzánk hasonló nagy mintán.

\section{Módszer}

\subsection{Résztvevők és eljárás}

A 34 tételes és 5-fokozatú válaszformátummal rendelkező Tellegen Abszorpció Skálával végzett vizsgálatban budapesti, kaposvári és pécsi egyetemek különböző karain tanuló nappali vagy levelező képzésben részesülő hallgató vett részt $(n=1935)$. A hallgatók túlnyomó többsége nő volt (1347 fő, 69,6\%), 9-en pedig nem jelölték meg a nemüket. Az önkéntes kitöltők életkora, a levelező képzésben résztvevő hallgatóknak köszönhetően, tág tartományban szórt: átlagéletkor 28,1 év, a szórás pedig 10,4 év. A legfiatalabb kitöltő 18 éves, míg a legidősebb 75 éves volt. A kérdőív kitöltésére csoportosan csendes helységben vagy egyénileg otthonos körülmények között került sor, több más önjellemző kérdőív felhasználásával ${ }^{1}$. A vizsgálat a Helsinki deklaráció szellemében a Pécsi Tudományegyetem Orvostudományi Kar kutatásetikai bizottságának engedélye alapján történt (az etikai engedély száma: 6732 PTE/2017).

1 Jelent tanulmányunkban csak a Tellegen Abszorpció Skála elemzésének eredményeit szemléltetjük, más módszerekkel történő összevetésre a terjedelmi korlátok miatt nem vállalkozunk. 
A TAS dichotóm változatának elemzését két korábbi vizsgálatból származó egyesített adatbázison végeztük el. Az egyik adatbázis 210 fó TAS eredményeit tartalmazta, akik egy poszttraumás növekedést vizsgáló kutatásban vettek részt (Rózsa, Reinhardt, \& Kulcsár, 2006). A minta három jól elkülönülő csoportból állt: 1. és 2. típusú diabéteszben szenvedő személyek (60 és 48 fő), illetve nemben és korban illesztett kontrollcsoport (102 fó). A 210 fős minta 69\%-át nők alkották, az átlagéletkor pedig 41,5 év (szórás: 17,8 év) volt. A másik adatbázis két Facebookon található szerepjáték csoport önkéntes kitöltőiből állt ( $n=189$ ), akiknek az átlagéletkora 27,8 év (szórás: 6,5 év) volt, és a férfiak aránya enyhén magasabb volt (53,4\%), mint a nőké (Nagy, 2016).

\subsection{A Tellegen Abszorpciós Skála (TAS) bemutatása}

A Tellegen Abszorpciós Skála (Tellegen \& Atkinson, 1974) Varga Katalin által magyarra fordított változatának hazai adaptációját Simor és munkatársai (2011) végezték el. Az általuk használt kérdőív tételeit változtatás nélkül átvettük, de az igaz - nem igaz válaszalternatívákat a nemzetközi példát követve (Carleton és mtsai, 2010; Parsons, Barnett, \& Melugin, 2015) a jobban differenciáló 5-fokozatú skálára cseréltük. Tellegen (1992; id. Simor és mtsai, 2011) eredeti, de nem publikált kézirata 6 megbízható faktort említ. Az A lebilincseló élményekre való fogékonyság (Responsiveness to engaging stimuli) alskála a külső ingerre fókuszált, de a tudatot beszúkító figyelem mértékét detektálja. A Szinesztézia (Synesthesia) alskála a multimodális ingerek integrációjának mérési lehetőségét biztosítja, és szintén külső ingerre irányul, de a tudatot beszúkítő kognitív funkcióval jellemezhető. A Kiterjesztett kogníció (Enhanced cognition) alskála külső ingerekre élményvezérelt, fokozott képzeleti tevékenységgel kibővített abszorpciójával jár együtt. $\mathrm{Az}$ A tevékenységekben való teljes elmerülés (Obvious/dissociative involvement) alskála a belső élményekre való figyelmet és az ezzel párhuzamosan megjelenő beszúkült tudatállapot mértékét méri. Az emlékek élénksége (Vivid reminiscence) alskála a felidézésére való hajlamot, az élénk múltbeli képek jelen világra való kivetítésének mértékét regisztrálja. A Kiterjesztett tudatosság (Enhanced awareness) alskála a környezeti eseményekben való fokozott ottlét „,being there, presence” érzés megjelenésének gyakoriságát méri fel (Tellegen, 1992; id. Simor és mtsai, 2011). A felsorolt TAS faktorokat a kulturális hatások jelentősen befolyásolják. A különböző nemzetek számára készült adaptációk esetében nem minden esetben tudták a fenti faktorokat reprodukálni, következésképpen a tételek besorolása is gyakran változik (Carleton és mtsai, 2010; Jamieson, 2005). A hazai vizsgálatok és más nem- 
zeti vizsgálatok eredményei is arra utalnak, hogy célszerú a TAS egyfaktoros változatát használni (Ritz \& Dahme, 1995; Simor és mtsai, 2011). Ebben az esetben azonban a tudatállapotokra, a figyelem fókuszára és a kognitív tevékenység jellegére vonatkozó faktorokban lévő interpretációs lehetőségek korlátozottá válnak (Jamieson, 2005; Simor és mtsai, 2011). Úgy gondoljuk, hogy a TAS által felmért abszorpció személyiségvonás alkalmas a modern pszichopatológiai gondolkodásmódban alkalmazott dimenzionális és vulnerabilitás alapú modellek vizsgálatára. Ez a törekvés - széleskörú egészséges és páciens populáció vizsgálatával - megkívánja a feltárt faktorok megbízhatóságának növelését és további eszközök bevonásával azok tartalmának pontosabbá tételét.

Elemzésünk második részében a 34 tételes TAS dichotóm válaszformátumú változatát is elemezzük. Ennél a változatnál az Igaz válaszok 1 pontot, míg a Nem igaz válaszok 0 pontot kapnak. A magasabb pontszám a fokozott abszorpciót jelzi. A kérdőív nem tartalmaz fordított tételt, így az összpontszám 0-tól 34 pontig terjedhet. Mint ahogy már korábban megjegyeztük, a kevés tételból álló alskálák (pl. Az emlékek élénksége, 3 tétel) általános problémája, hogy az értékek kevéssé szórnak, az elérhetó pontszám 0 és 3 pont közötti, ami elemzési és értelmezési nehézségeket egyaránt hordozhat. Tellegen (1982) kiváló belső konzisztenciáról (Cronbach-alfa: 0,88) és magas teszt-reteszt megbízhatóságról $(0,91)$ számol be egyetemi hallgatói mintán. A kiváló teszt-reteszt reliabilitást $(0,85)$ más szerző tanulmánya is alátámasztja (Kihlstrom és mtsai, 1989).

\subsection{Adatelemzési módszerek és stratégia ${ }^{2}$}

A TAS 5-fokozatú és a dichotóm válaszformátumú adatait az eredmények összehasonlításának érdekében hasonló módon elemezzük. Elsőként a tételek egy- és többváltozós normalitását vizsgáljuk, mivel ennek eredménye meghatározza a faktorelemzésnél alkalmazott becslési módszert. Ezt követően az eredeti feltételezéseknek megfelelő egy- és hatfaktoros struktúrát

2 Az adatelemzési módszerek és stratégia jelen bemutatása nem teljes, mivel a későbbiekben számos más módszer is alkalmazásra kerül. Az itt be nem mutatott módszereket a tanulmányunk későbbi fejezeteiben részletesen is ismertetjük, de úgy gondoljuk, hogy ezen módszerek késóbbi bemutatása didaktikai szempontból jól tükrözi az elemzési módszerek megválasztásának szempontjait, és jelzi azt is, hogy gyakran a kapott eredmények határozzák meg, hogy milyen kiegészítő elemzéseket célszerú alkalmazni. Ebből az elrendezésből láthatóvá válik, hogy egy átfogó pszichometriai elemzés mennyire tervezhető előre, és mennyire a kapott eredmények határozzák meg az újabb módszerek alkalmazását. 
tesztelünk megerősítő (konfirmatív) faktorelemzéssel. A különböző faktormegoldásoknál igyekszünk többféle elrendeződést is megvizsgálni: egydimenziós szerkezet, korreláló faktorok, másodlagos faktorok és bifaktoros modell. A kapott eredményektől függően további feltáró faktorelemzéseket tervezünk, ahol az egyes tételek pszichometriai sajátosságait igyekszünk megragadni, különös figyelmet szentelve megbízható aldimenziók létrehozására és ezek alkalmazhatóságának tesztelésére.

A megerősítő faktorelemzések során az adatok és a teoretikus modell egybeesésének mértékét jelző illeszkedési mutatóknál a módszertani ajánlásokban megfogalmazott kritériumokat használjuk (pl. Anderson \& Gerbing, 1984; Bentler, 1990; Cole, 1987; Marsh \& mtsai, 1988; Tanaka, 1993). Általánosan elfogadott és ajánlott, hogy a modell illeszkedésének jóságát több kritérium alapján ítéljük meg. Az egyik leggyakrabban használt illeszkedési mutató a $\chi^{2}$-próba értéke, amelyet általában akkor tekinthetünk elfogadhatónak, ha a szabadságfokhoz viszonyított értéke alacsony (pl. kisebb, mint a szabadságfok kétszerese) és nem szignifikáns $(p>0,05)$. Ennek a mutatónak azonban több korlátja létezik. A legjellemzőbbek a többváltozós normalitás sérülésére és a mintanagyságra való érzékenység. Számos empirikus eredmény és szimulációs vizsgálat támasztja alá, hogy a normalitás sérülésekor vagy nagy elemszámú minta esetén a $\chi^{2}$-próba kevésbé informatív, a legtöbb esetben a modell elvetését jelzi (Bentler \& Bonnet, 1980; Jöreskog \& Sörbom, 1993; McIntosh, 2006). A mintanagyságból fakadó korlátot gyakran a $\chi^{2}$-próba szabadságfokhoz mért arányával próbálják kompenzálni $\left(\chi^{2} / \mathrm{df}\right)$, amelynek ugyan nincs pontos kritériuma, de az ajánlások általában 2-tól 5-ig terjednek (Tabachnick \& Fidell, 2007; Wheaton, Muthen, Alwin, \& Summers, 1977).

Elemzéseink során a $\chi^{2}$-mutató mellett az alábbi illeszkedési mutatókat vesszük figyelembe: összehasonlító illeszkedési mutató (Comparative Fit Index, CFI), Tucker-Lewis-féle illeszkedési mutató (Tucker-Lewis Non-normed Fit Index, TLI; Tucker \& Lewis, 1973), valamint a becslési hiba négyzetes átlagának gyöke (Root-Mean-Square Error of Approximation, RMSEA; Steiger, 1990). ${ }^{3}$

A CFI azt méri fel, hogy egy feltételezett hipotetikus modell milyen mértékben reprodukálja a valós adatokon nyugvó kovariancia-mátrixot egy független modellhez képest. A TLI a CFI-hez hasonló módon méri az illeszkedést, annyi különbséggel, hogy ez a mutató a modellben használt szabad-

\footnotetext{
3 Érdemes megjegyezni, hogy a fenti illeszkedési mutatóknak nincs széles körben elterjedt magyar megfelelóje, a kutatók leginkább az angol rövidítéseket alkalmazzák. A továbbiakban mi is a rövidítésekkel hivatkozunk a mutatókra.
} 
ságfokot is figyelembe veszi, így kiküszöböli a vizsgálati minta méretének befolyásoló szerepét. A CFI és TLI mutatók értéke 0 és 1 közötti tartományba eshet, ahol az 1-hez közeli érték jelzi a szoros illeszkedést. Kezdetben a mutatók elfogadhatósági kritériumának 0,90-et adtak meg, de az utóbbi időkben inkább a 0,95-ot tekintik az elfogadhatóság alsó határának (Hu \& Bentler, 1999). A Steiger-féle RMSEA-mutatót a modell populációs kovariancia mátrixához viszonyított illeszkedésének becsléséhez használjuk. Az RMSEA az elemszámtól függetlenül hasonlítja össze, hogy a valós és az optimális paraméterekkel rendelkező hipotetikus modell kovariancia mátrixa milyen mértékben illeszkedik. Az RMSEA a modell takarékosságának megbízható jelzője, a komplex modellek hibás specifikálásának hatékony mutatója. Az RMSEA értéke is 0 és 1 közé eshet, itt azonban a kisebb, 0-hoz közel eső érték jelzi a jobb az illeszkedést. Browne és Cudeck (1993) meghatározása szerint az RMSEA értékei 0,05-ig szoros illeszkedést jeleznek; 0,08-os értékig pedig megfelelő illeszkedést, elfogadható populáción belüli becslési hibákkal.

A statisztikai elemzéseket SPSS 22 (IBM Corp., 2013) és MPLUS 8.2 (Muthén \& Muthén, 1998-2017) programokkal végeztük.

\title{
3. Eredmények
}

\subsection{A TAS 5-fokozatú válaszformátumú változatának elemzése}

\author{
3.1.1. Elözetes elemzés: Normalitásvizsgálat \\ és az eredeti faktorszerkezet megerösitő faktorelemzése
}

Mivel a faktorelemzés eredményét - különösen a legnagyobb valószínúségi elven alapuló becslések esetében ${ }^{4}$ - jelentősen torzíthatja a változók normalitásának sérülése, így elsőként a változók eloszlását és normalitását (egy- és többváltozós) vizsgáltuk meg. Mivel a kérdőív tételeinek értékelése 5-fokozatú Likert-skálán történt, így ezek a változók nem tekinthetók folytonos intervallum skáláknak, így nem meglepő, hogy a normalitást tesztelő hagyományos próbák (pl. Kolmogorov-Smirnov-teszt, Shapiro-Wilk-teszt, Mardia-féle többváltozós ferdeség és csúcsosság mutató) kritériumainak ál-

\footnotetext{
4 Az egyik legáltalánosabb parametrikus becslési stratégia, amely szerint az ismeretlen paraméter azon értékét fogadjuk el, amely mellett a bekövetkezett eredmény maximális valószínúségú. $\mathrm{Az}$ angol nyelvú szakirodalomban maximum-likelihood néven ismert, és a legtöbb illeszkedési mutatót ehhez a becsléshez dolgozták ki.
} 
talában nem felelnek meg. A fentieknek megfelelően a pszichológiai kérdőívek Likert-skálás tételein inkább azt vizsgáljuk, hogy a változók normalitása milyen mértékben sérül. Bár nincs egyértelmúen meghatározott kritérium, a módszertani ajánlások szerint, a nagyobb elemszámú $(n>300)$ vizsgálati minták esetén, leginkább a ferdeség 2 alatti értéke, valamint a csúcsosság 7 alatti értéke elfogadható (Chou \& Bentler, 1995; Curran, West, \& Finch, 1996; Muthén \& Kaplan, 1985). A szimulációs vizsgálatok eredményei során az ez alatti normalitásmutatókkal rendelkező változók esetében a faktorelemzés eredményei még kevéssé torzulnak.

Mintánkon a ferdeség (skewness) és a csúcsosság (kurtosis) mutatók abszolút értékben egyetlen tétel esetében sem haladták meg az 1,5-et. Mindössze egyetlen 1-nél magasabb ferdeség mutatót találtunk (9. tétel), a csúcsosság mutatók közül pedig 8 tételnél mutatkozott abszolút értékben 1 és 1,2 közötti érték. A hagyományos egyváltozós normalitás tesztek (Kolmogorov-Smirnov- és Shapiro-Wilk-teszt) a legtöbb változó esetében a normalitás sérülését jelezték, illetve a többváltozós normalitás teszt (Mardia-féle többváltozós ferdeség- és csúcsosság mutató) is problémát jelezett.

Bár a megerősítő faktorelemzés az egyfaktoros és az eredeti Tellegen-féle hatfaktoros megoldások esetén is elfogadhatósági kritériumokhoz közel eső illeszkedési mutatókat adott (2. táblázat), ${ }^{5}$ ennek ellenére kihasználva a viszonylag nagy elemszámú vizsgálatot és a nemzetközi tapasztalatokat (pl. Jamieson, 2005), további feltáró (exploratív) faktorelemzés mellett döntöttünk, gondosan mérlegelve a lehetséges dimenziók számát, tartalmát és megbízhatóságát. Mivel az 5-fokozatú TAS esetében a vizsgált mintánk elemszáma megközelítette a 2000 főt, így a módszertani ajánlásokban (pl. Cabrera-Nguyen, 2010; Van Prooijen \& Van Der Kloot, 2001; Worthington \& Whittaker, 2006) megfogalmazottak szerint jártunk el: a mintánkat random módon két részre bontottuk, és az egyiken feltáró faktorelemzést készítettünk, míg a másikon a megerősítő faktorelemzést futattuk le. ${ }^{6}$

\footnotetext{
5 A megerősítő faktorelemzés eredményeit a későbbiekben - más modellek összevetésében részletesen is bemutatjuk és értelmezzük.

6 A különböző mintákon történő elemzés főként keresztvalidálási célokat szolgál. Könnyú belátnunk, hogy az azonos mintán készített elemzések sokkal jobb eredményeket adnak, mint az eltéró minták esetében. Természetesen a döntést több tényező is befolyásolhatja: pl. a vizsgálati minta nagysága, a tesztfejlesztés módja és célja.
} 


\subsubsection{Feltáró faktorelemzés}

A faktorelemzés feltétele, hogy a változók bizonyos redundanciát hordozzanak, így elsőként Kaiser-Meyer-Olkin- (KMO-) mutató segítségével azt vizsgáltuk, hogy a TAS tételei milyen szoros összefüggést mutatnak egymással. A 0 és 1 közé eső mutatónál általában a 0,9 feletti értéket kiválónak tekintik. Mintánkon a KMO értéke 0,96, amely eredmény azt jelzi, hogy változóink alkalmasak a faktorelemzésre. A következő lépésben azt kell eldöntenünk, hogy hány dimenzió valószínúsíthető. A főkomponens-elemzés öt 1-nél nagyobb sajátértékú (Kaiser-kritérium) dimenziót jelzett, a következő sajátértékekkel: 12,1; 1,6; 1,4; 1,3 és 1,1. Az 5 komponens az összes tétel által leírt összvariancia 51,7\%-t ragadja meg. Látható, hogy az első komponens kiugróan magas sajátértékkel rendelkezik a rákövetkező értékekhez képest, és az összvariancia 35,6\%-át magyarázza. A rákövetkező komponensek által magyarázott variancia komponensenként 3 és 5\% közötti. A faktorok számát gyakran a sajátértékek lefutási görbéjéből (lejtődiagram) állapítják meg, és azt vizsgálják, ahol a görbe meredeksége hirtelen megváltozik és egyenesbe kezd átfordulni (Scree-teszt). Esetünkben ez egydimenziós szerkezetet jelent, ami az elvárásokkal egybe is esik. Ugyanakkor azt is mérlegelni kell, hogy az egyetlen dimenzió az összes tétel varianciájának csak kis hányadát magyarázza. A társadalomtudományokban általánosan elfogadott, hogy az 50-60\%-os magyarázóerőt már elfogadhatónak tekintjük. Ezen kritérium alapján inkább egy többfaktoros megoldás biztosíthatná a megfelelő varianciahányadot.

Mivel Jamieson (2005) ausztrál kutatási eredményei is az 5-faktoros struktúrát erősítettek meg, így mi is megvizsgáltuk, hogy a TAS tételei milyen jól illeszthetők az 5-faktoros szerkezetre. A korábbi eredmények alátámasztják, hogy a faktorok közötti korreláció számottevő, ezért a Jamieson által is használt becslési módszert és forgatást választottuk: főtengelyelemzést és ferde forgatást.

Az 1. táblázatban a TAS 34 tételén végzett feltáró faktorelemzés eredményét láthatjuk. A 0,3 alatti faktorsúlyokat nem tüntettük fel, a 0,4 vagy annál magasabb faktorsúlyokat pedig félkövér betúvel emeltük ki. A táblázat utolsó oszlopában a kommunalitás (H) mutatókat jelezzük, ami azt fejezi ki, hogy az egyes tételek varianciáját a faktorok mennyire ragadják meg. A legalacsonyabb értékeket az 1 . és a 30. tételnél láthatjuk, ahol az 5 faktor a tételek varianciájának csak a $26 \%$-át, illetve $34 \%$-át magyarázza. Bár pontos határértéket nem szoktak megnevezni, de általában 0,5-nál magasabb kommunalitás mutatókat tartanak kívánatosnak, amely érték természetesen függ a faktorok számától. 
Szürke háttérrel azokat a faktorsúlyokat emeltük ki, amelyek 0,4-nél nagyobbak és a faktorhoz tartalmilag jól illeszthetők: pl. az eredeti hatfaktoros megoldásnál is hasonló dimenzióba szerveződtek vagy a tétel tartalma alapján illeszkedik a faktorba. Az első faktor esetében a legnagyobb faktorsúllyal rendelkező tételek az eredeti 6-faktoros megoldás során is egy dimenzióba rendeződtek, amelynek Tellegen az A tevékenységekben való teljes elmerülés nevet adta. Bár az 5. tétel a tellegeni felosztásban a Kiterjesztett tudatosság dimenzióhoz tartozott, tartalmát tekintve („Néha úgy érzem, mintha gondolataim magukba zárnák az egész világot") azonban jól illeszthető a tevékenységekben való elmerüléshez is. Igyekeztünk olyan tételeket kiválasztani, amelyek az eredeti felosztásban is hasonló dimenzióba rendeződtek, még akkor is, ha az adott tétel más faktorral is szoros együttjárást adott: pl. 14. tétel. A kapott faktorok megfeleltethetőek a tellegeni felosztásnak, bár az 1. táblázatból látható, hogy sok tétel az eredeti felosztásból máshová sorolódott, mint amit elvárnánk. Az eredeti 6-faktoros megoldásból a 3 tételből álló „Az emlékek élénksége” dimenzió eltúnt, két tétele (1. és 4. item) az első faktorba, míg a harmadik tétele (19. item) a második faktorba került. A kapott különbségek értelmezésénél fontos azt is mérlegelnünk, hogy Tellegen igaz - nem igaz válaszformátumú kérdóívvel dolgozott, míg a jelen tanulmányban 5-fokozatú válaszformátumot alkalmaztunk. Mivel a tellegeni faktorelemzés eredményei kiadatlan kéziratban jelentek meg (Tellegen, 1992), így nem volt lehetőségünk további összehasonlító vizsgálatokra. Az általunk kiválasztott 5 skála (faktoronként szürke háttérrel kiemelve) belső konzisztenciáját becslő Cronbach-alfa mutatók elfogadható megbízhatóságot jeleznek: értékük 0,73 és 0,78 között ingadozik. ${ }^{7}$

\footnotetext{
7 A mutató elfogadhatósági kritériumaként általában a 0,70-et szoktak megadni, a 0,80 feletti értékeket pedig jó megbízhatóságnak lehet értékelni (Nunnally, 1978).
} 
Rózsa Sándor

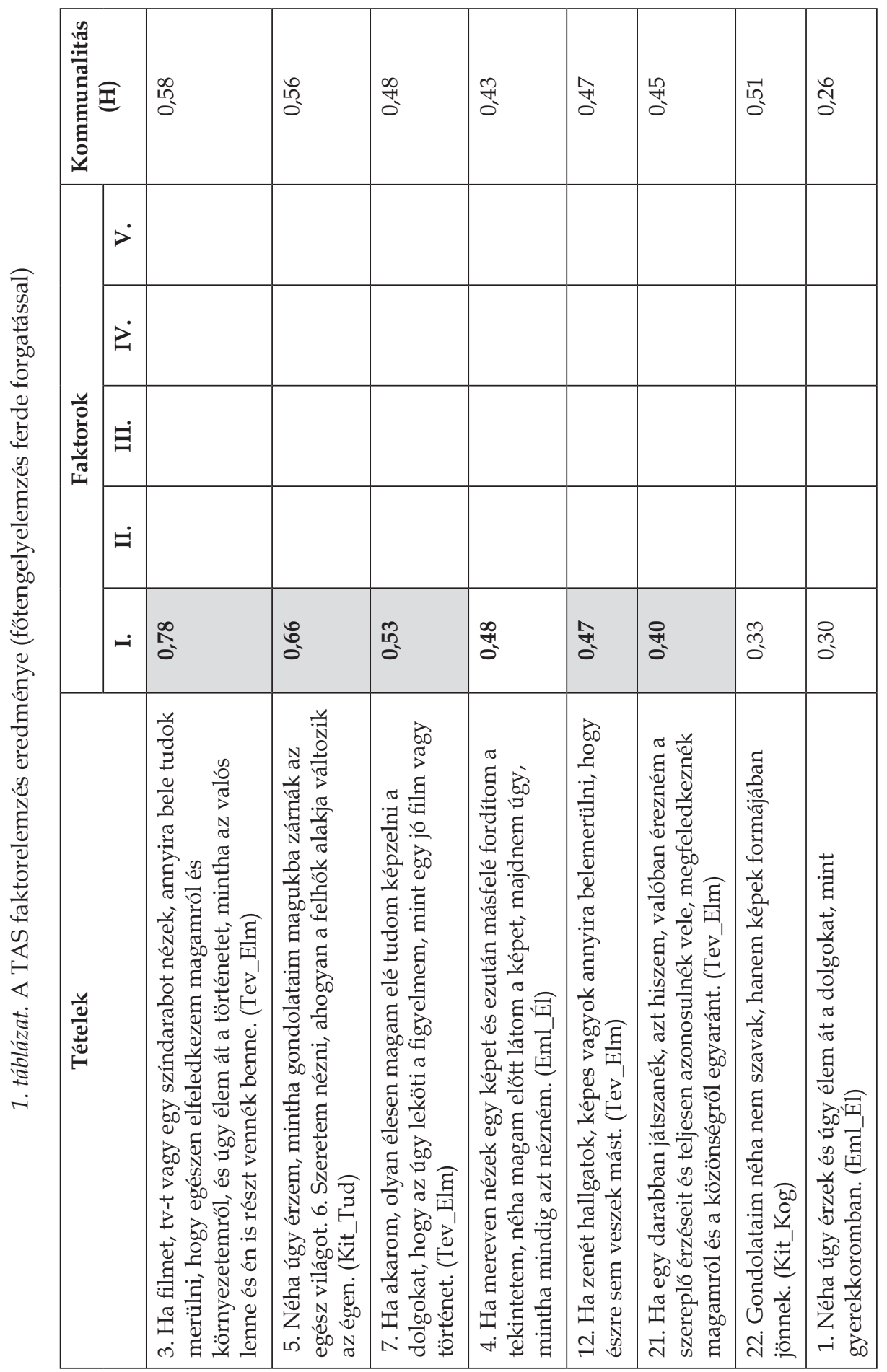




\begin{tabular}{|c|c|c|c|c|c|c|c|c|c|c|c|}
\hline 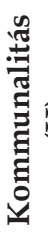 & & $\begin{array}{l}\text { Ln } \\
\text { ถ2 }\end{array}$ & $\stackrel{8}{8}$ & $\begin{array}{l}\text { చే } \\
\text { ᄋ̊ }\end{array}$ & ถุ & 余 & 告 & ڤి & 용 & $\stackrel{\mathscr{P}}{0}$ & ஹु' \\
\hline & $\vec{\prime}$ & & & I্ & & 忍 & & & & & \\
\hline & $Z$ & & & & & & $\begin{array}{l}\infty \\
\stackrel{2}{n} \\
\sigma^{\prime}\end{array}$ & & & & \\
\hline $\begin{array}{l}0 \\
\frac{0}{t}\end{array}$ & 白 & & & & & & & & & & \\
\hline & $\dot{\Xi}$ & 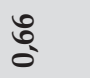 & 응 & $\begin{array}{l}\stackrel{0}{0} \\
\stackrel{\circ}{\circ}\end{array}$ & 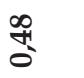 & 융 & ్ㅗㅇ & 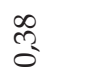 & $\begin{array}{l}\text { N } \\
\text { ô }\end{array}$ & हु & \\
\hline & $\dot{\sim}$ & & & & & & & & & & \\
\hline 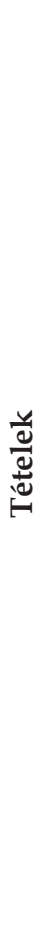 & & 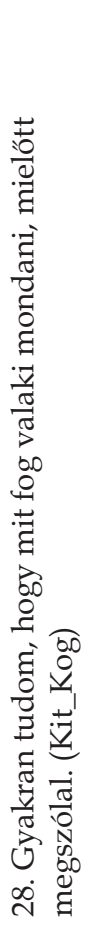 & 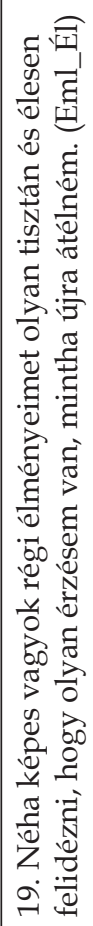 & 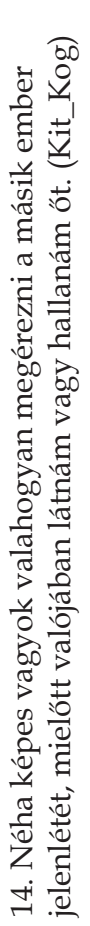 & 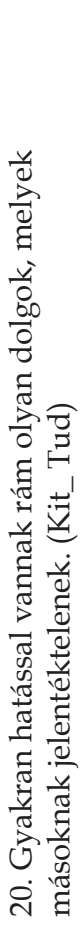 & 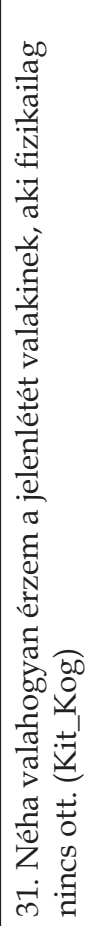 & 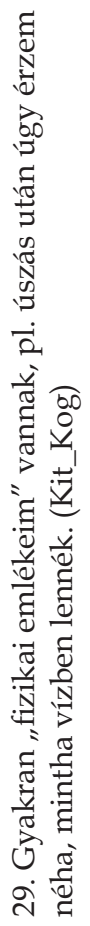 & 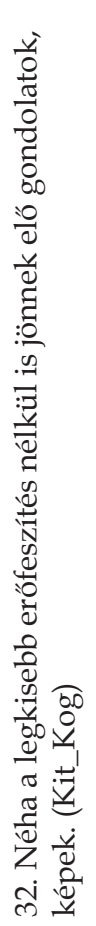 & 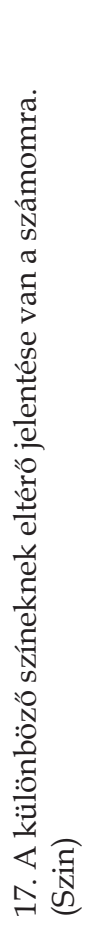 & 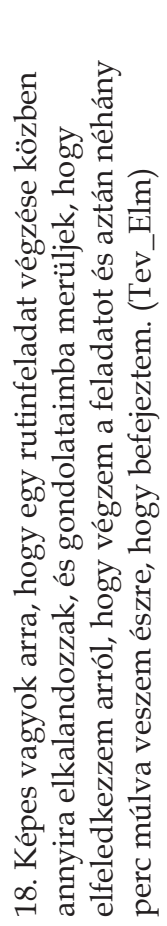 & 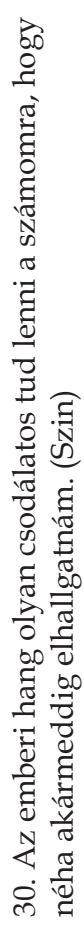 \\
\hline
\end{tabular}




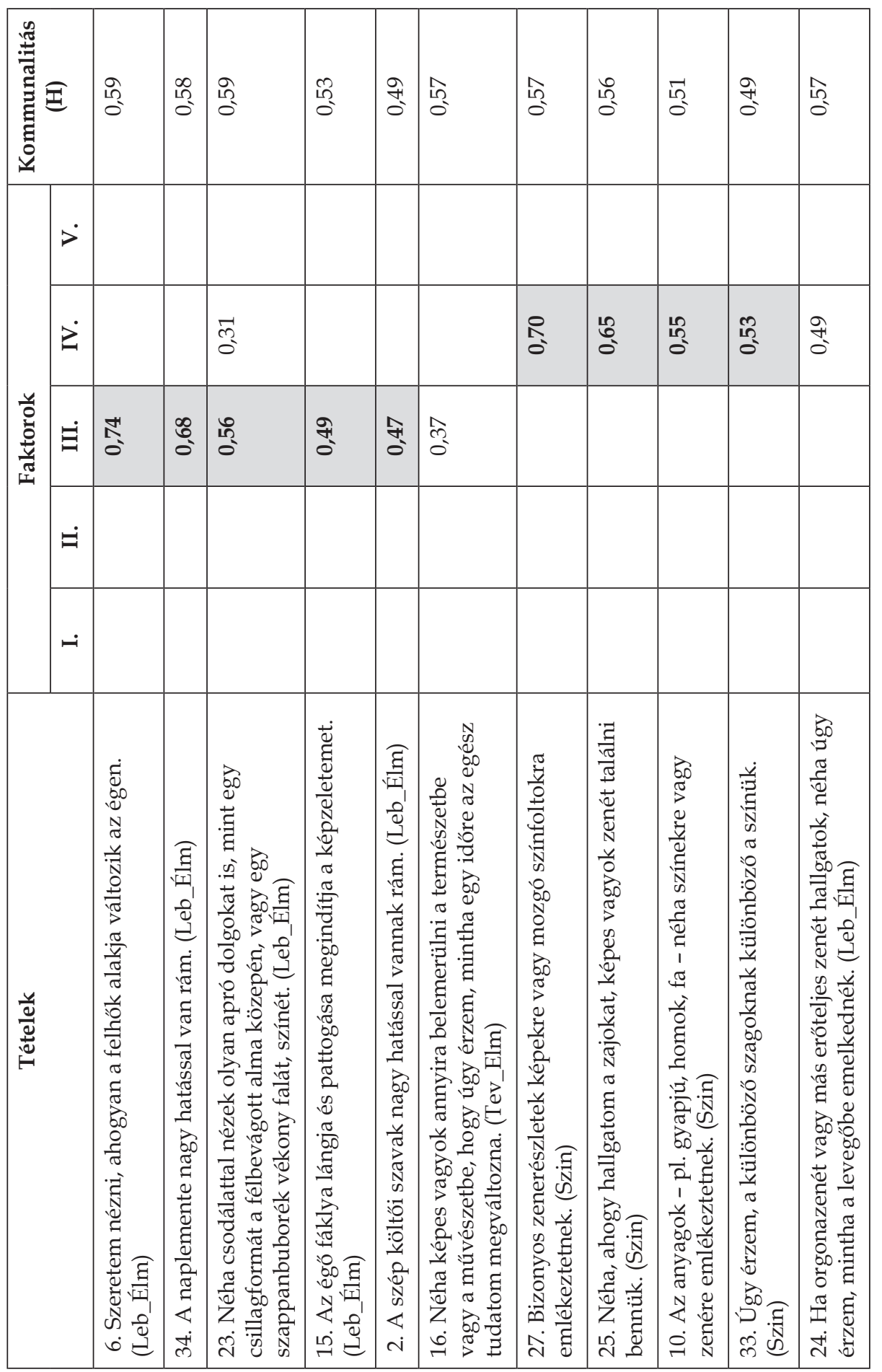




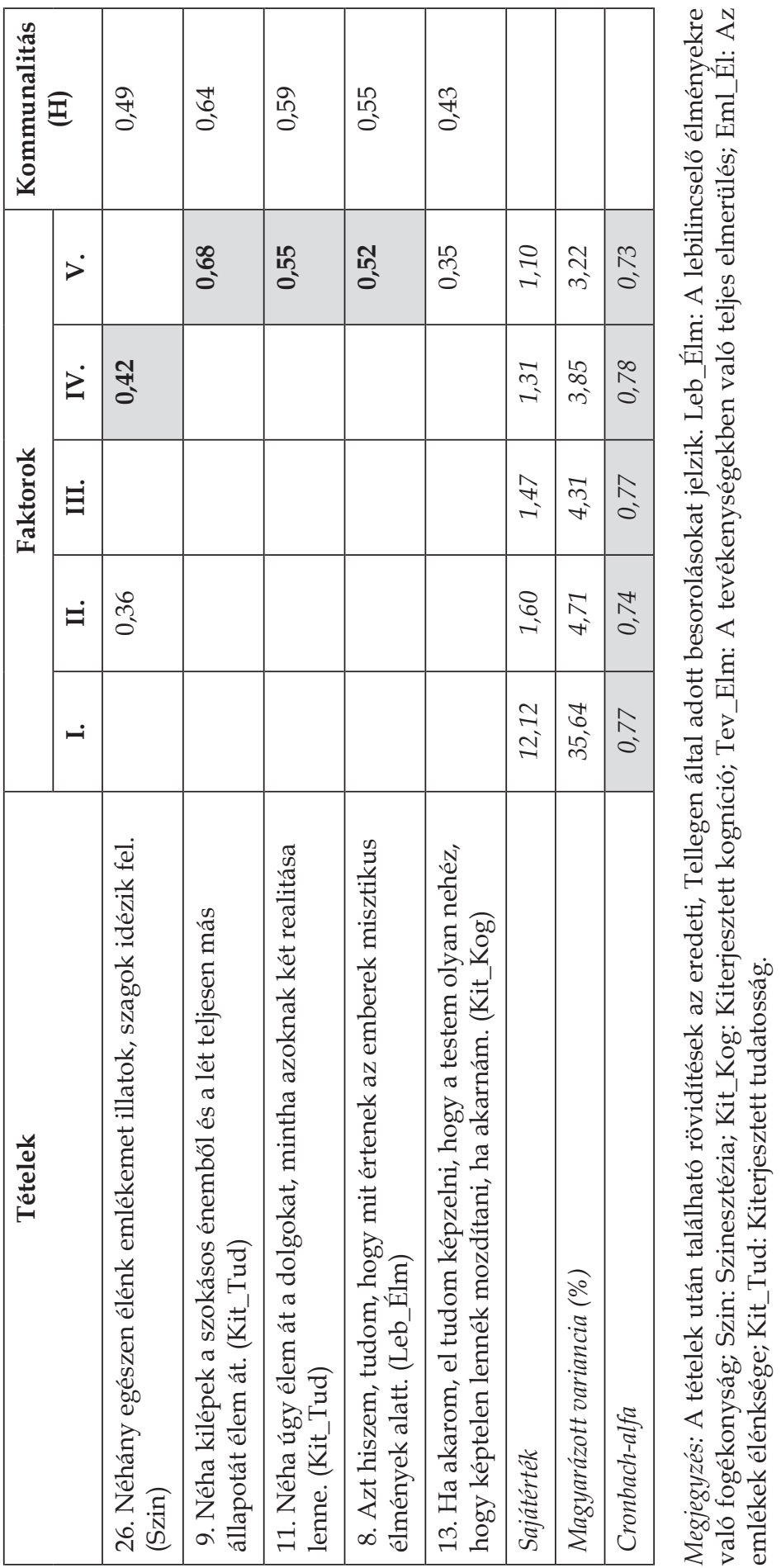


Eredményeinket a Jamieson (2005) által kidolgozott 5 faktoros szerkezettel is összehasonlítottuk. A két eredmény jól összevethető, hiszen az ausztrál kutató is a TAS 5-fokozatú válaszformátumát alkalmazta 352 fős, elsőéves pszichológushallgatókból álló mintáján, illetve mi is hasonló módszerekkel (főtengelyelemzés, ferde forgatás) végeztük el a feltáró faktorelemzést. Mivel Jamieson tanulmányában a faktorsúlymátrixot is publikálta, így lehetőségünk volt arra, hogy ezt a saját faktorsúlymátrixunkkal az ún. Prokrusztész-elemzés segítségével is összehasonlítsuk. ${ }^{8}$ A prokrusztészi ágyhoz hasonlóan az ausztrál mintán kapott faktorsúlymátrixot statisztikai eszközökkel (faktorforgatás) a hazai eredményekhez igazítottuk, az összeillés mértékét pedig kongruencia-együtthatókkal jellemeztük. A kongruenciamutató 0-tól 1-ig terjedő szám, és az egyhez közel eső értékek jelentik a szoros egybeesést. Általában a 0,95-ot meghaladó értéket tekintik jó faktorkongruenciának, a 0,85 és 0,95 közötti értéket pedig még elfogadhatónak (Digman, 1967; McCrae és mtsai, 1996). A legmagasabb kongruencia-együtthatót az A lebilincselő élményekre való fogékonyságnál (III. faktor) kaptuk, amelynek értéke 0,90. A II. (Kiterjesztett kogníció) és V. (Kiterjesztett tudatosság) faktor esetében a mutatók értéke 0,88 és 0,85, míg az I. (A tevékenységekben való teljes elmerülés) és IV. faktor (Szineztézia) esetében a kongruencia együttható 0,73 . Az egyes tételek kongruencia-együtthatói változatos eredményeket adtak. A 34 tételből csak néhány esetben (6., 19., 26., 28., 31.) kaptunk 0,95-nál nagyobb értéket. A kongruencia-együtthatók átlaga 0,81 . Kiugróan alacsony érték mutatkozott a következő tételeknél: 4 . Ha mereven nézek egy képet és ezután másfelé fordítom a tekintetem, néha magam előtt látom a képet, majdnem úgy, mintha mindig azt nézném (kongruencia-együttható: 0,53); 25 . Néha, ahogy hallgatom a zajokat, képes vagyok zenét találni bennük (kongruencia-együttható: 0,28); 30. Az emberi hang olyan csodálatos tud lenni a számomra, hogy néha akármeddig elhallgatnám (kongruencia-együttható: 0,55).

\subsubsection{Megerösítő faktorelemzések}

A feltáró faktorelemzések során a lehetséges dimenziók számát, és a tételek faktorba szerveződését vizsgáltuk. Láthattuk, hogy bizonyos tételek akár több faktorral is kapcsolatba hozhatók, illetve olyan tételt is találtunk (pl. 30.), amelynek a faktorsúlya egyik faktoron sem érte el a 0,3 értéket. A kö-

8 A módszerról bóvebben Digman (1967) vagy McCrae, Zonderman, Costa, Bond, \& Paunonen (1996) tanulmányaiban olvashatunk. 
vetkezőkben alkalmazott megerősítő faktorelemzésekkel arra keressük a választ, hogy adataink milyen jól illeszkednek különböző hipotetikus faktormodellekre. A tételeket úgy specifikáljuk, hogy a feltételezett sajátfaktorral tökéletes kapcsolatot mutasson (faktorsúly: 1), más nem saját faktorral pedig ne korreláljon (faktorsúly: 0). A statisztikai program azt vizsgálja, hogy az adatok mennyire illeszkednek az így meghatározott struktúrára, az összeillés mértékét pedig a korábban bemutatott illeszkedési mutatók segítségével ítélhetjük meg.

Mérlegelve a változóink normalitásának sérülését és az 5-fokozatú válaszformátumot, az ilyen esetekben ajánlott két, különböző elvekre épülő robusztus becslési eljárást alkalmaztuk. Az első a súlyozott legkisebb négyzetes eljárás (Weighted Least Squares Mean and Variance adjusted: WLSMV) módszere volt, amely nem kívánja meg a változók normális eloszlását, és a kategorikus vagy ordinális kérdőív-tételek elemzésének ajánlott módszere (Brown, 2006). ${ }^{9}$ Elemzéseinket azonban elvégeztük a legnagyobb valószínúségi elven alapuló becslési eljárás (Maximum-likelihood: ML) robusztus változatával (MLR) is. A két becslési eljárás alapvető különbsége, hogy a WLSMV probit, míg az MLR logisztikus regressziót alkalmaz. ${ }^{10}$ Jelen tanulmányunkban a WLSMV becsléssel kapott eredményeket szemléltetjük, és jelezzük, ha a két becslési eljárás lényegesesen eltérő eredményt mutat.

Az alábbi elemzéseknél az eredeti 34 tételes és a feltáró faktorelemzéssel nyert 23 tételes változatokat vetettük össze. A 34 tételes változat esetében az eredeti elképzeléseknek megfelelő 1 és 6 faktoros struktúrát, míg a 23 tételes változatban 1 és 5 faktoros struktúrát teszteltünk. Emlékeztetóül megjegyezzük, hogy a válaszformátum mindkét esetben 5-fokozatú volt. Mindkét változat esetében négy faktorszerkezetet teszteltünk: 1. egydimenziós struktúra; 2. 5-, illetve 6-dimenziós struktúra a faktorok közötti korrelációval; 3. faktormodell másodrendú faktorral; 4. bifaktoros modell. Az 1. ábra a 4 hipotetikus faktormodell elrendeződését szemlélteti, az egyszerúbb ábrázolás kedvéért 9 tételt és 3 faktor vettünk alapul. Az egydimenziós szerkezet esetében minden tétel egyetlen faktorral mutat kapcsolatot (a) Egyfaktoros modell). Több kutató is úgy véli, hogy ezzel a faktorszerkezettel jellemezhetó leginkább a Tellegen Abszorpciós Skála. A többfaktoros megoldásoknál eltéró modelleket különböztethetünk meg, aszerint, hogy a faktorok milyen

\footnotetext{
${ }^{9}$ Fontos megjegyeznünk, hogy elemzéseinket más becslési módszerekkel is elvégeztük (pl. MLR, ULS), és ahol számottevő eltérést kaptunk azt jeleztük.

10 A probit és a logisztikus regresszió alapvetően a valószínúség eloszlás feltételezésében különböznek. A logit módszer azzal a feltételezéssel él, hogy az odds arány logaritmusa lineárisan függ a magyarázó változóktól, míg ezzel szemben a probit analízis feltételezése, hogy a P valószínúség standard normális eloszlást követ.
} 
kapcsolatban vannak egymással. A kapott faktorokat tekinthetjük akár függetlennek is, és közöttük csak korrelációt feltételezünk (b) Modellfaktorok korrelációjával). A faktorok egy magasabb rendú faktorba (Fm) is szerveződhetnek (c) Modell másodrendú faktorral), vagy elkülöníthetünk olyan modellt is, amelyben az egyes tételek egyidejúleg egy általános dimenzióba (Fg) és specifikus faktorokba is szerveződnek (d) Bifaktoros modell).

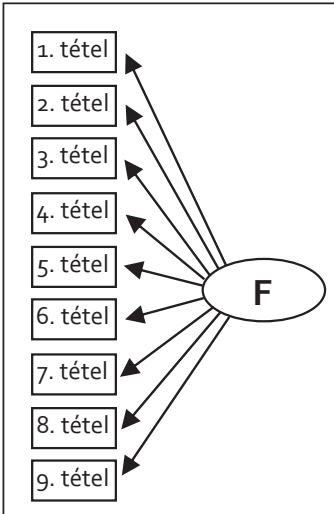

a) Egyfaktoros modell

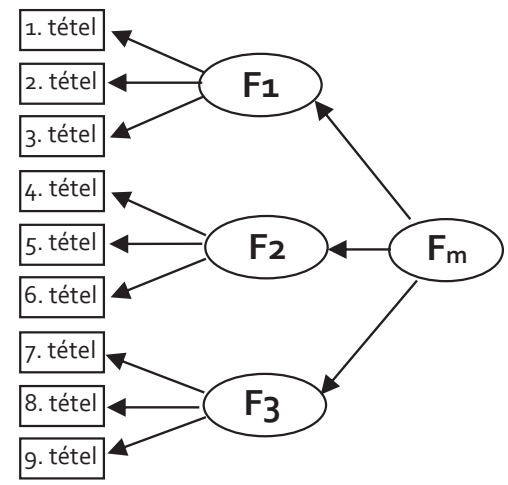

c) Modell másodrendü faktorral

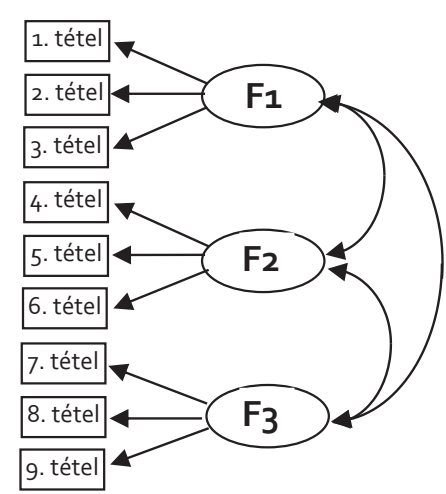

b) Modellfaktorok korrelációjával

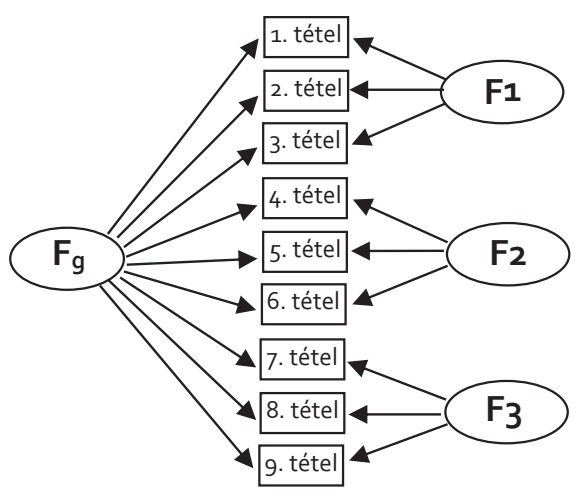

d) Bifaktoros modell

1. ábra. Példa hipotetikus faktorszerkezetekre

Mind a 34, mind a 23 tételes változat esetében az egydimenziós szerkezet illeszkedési mutatói voltak a legalacsonyabbak, a bifaktoros modellé pedig a legjobbak (2. táblázat). A legjobb illeszkedésú modelleket szürke háttérrel emeltük ki. Ha a CFI és TLI mutatók esetében a 0,95-ot vesszük az elfogad- 
hatósági kritérium alsó határának, akkor a TAS 34 tételes változatánál egyik modell illeszkedését sem tekinthetjük egyértelmúen elfogadhatónak, bár a mutatók mind a négy modell esetében közel hasonló mértékú illeszkedést mutatnak. Érdemes megjegyezni, hogy hasonló eredményt kaptak Simor és munkatársai (2011) is hazai mintán a dichotóm válaszformátumú TAS esetében, bár elemzéseik során bifaktoros modellt nem teszteltek. Ök az alacsony belső konzisztencia mutatókra hivatkozva javasolták az egydimenziós szerkezet szerinti értékelést.

A 23 tételes változat illeszkedési mutatói, az egydimenziós modelltől eltekintve, összességében jobbak, mint a 34 tételes változaté, amelynek hátterében elsődlegesen az áll, hogy a gyengébb pszichometriai mutatókkal rendelkező tételeket elhagytuk, a faktorstruktúrát „tisztítottuk”. A rövidített 23 tételes változatnál már sokkal magasabb Cronbach-alfa értékeket látunk (1. táblázat), így felmerül, hogy ez a rövidített változat alkalmas a fődimenzió mellett további aldimenziók megragadására is.

2. táblázat. A TAS különböző változatainak illeszkedési mutatói

\begin{tabular}{|l|c|c|c|c|c|}
\hline \multicolumn{7}{|c|}{ Modell } & $\chi^{\mathbf{2}}$ & df & RMSEA & CFI & TLI \\
\hline TAS-34 & 2792,63 & 527 & 0,066 & 0,922 & 0,917 \\
\hline egydimenziós & 2265,66 & 512 & 0,059 & 0,940 & 0,934 \\
\hline hatfaktoros ferde & 2393,68 & 521 & 0,060 & 0,936 & 0,931 \\
\hline másodlagos faktor & 1903,63 & 492 & 0,054 & 0,952 & 0,945 \\
\hline bifaktoros & 1826,96 & 230 & 0,084 & 0,907 & 0,897 \\
\hline TAS-23 & 938,89 & 220 & 0,058 & 0,958 & 0,952 \\
\hline egydimenziós & 1051,96 & 225 & 0,061 & 0,952 & 0,946 \\
\hline ötfaktoros ferde & 769,58 & 207 & 0,053 & 0,967 & 0,960 \\
\hline másodlagos faktor
\end{tabular}

Megjegyzés: a tételekre 5-fokozatú Likert-skálán történt a válaszadás.

Ezen a ponton, csakúgy, mint Jamieson (2005), mi is befejezhetnénk az elemzéseket, ha nem tartanánk zavarónak azt a tényt, hogy a feltáró faktorelemzés során egy nagyon erős első komponenst láthattunk, a rákövetkező komponensek magyarázó ereje pedig ettól jóval gyengébb volt. Vajon a többfaktoros modell dimenziói valóban alkalmasak arra, hogy az abszorpció bizonyos alfaktorait megbízhatóan megragadjuk? 
A következőkben azt vizsgáljuk, hogy milyen érvényességú és megbízhatóságú információkat nyerünk a bifaktoros modell segítségével. Ez a kiértékelési mód a gyakorlatban tehát egy abszorpció főskála alkalmazását és mindezek mellett további alskálák használatát jelenti. Elsőként a TAS-34-et, majd a rövidített TAS-23 standardizált faktorsúlyait és megbízhatóságát jelző mutatókat szemléltetjük.

A fö- és az aldimenziók reliabilitásának vizsgálata előtt érdemes kitérnünk a klasszikus tesztelméleten nyugvó és széles körben alkalmazott Cronbach-alfa mutató korlátaira. A mutató alkalmazásának egyik legfontosabb kritériuma, hogy olyan egydimenziós konstruktumok vizsgálatára alkalmas, ahol a faktorsúlyok azonosak (tau-ekvivalens modell), a mérési hibák pedig korrelálatlanok. Sajnos az egydimenziós szerkezet és az azonos faktorsúlyok a legtöbb pszichológiai konstruktum esetében nem biztosíthatóak, így ez a mutató általában pontatlanul becsli a belső megbízhatóságot (Cho, 2016; Dunn, Baguley, \& Brunsden, 2014). Alternatív megoldásnak tekinthetó a McDonald (1999) által bevezetett omega ( $\omega$ ) együttható, amely azt fejezi ki, hogy az összpontszám varianciájának mekkora hányada magyarázható a közös faktorral vagy faktorokkal. Ezt a mutatót az aldimenziók megbízhatóságának jellemzésére is alkalmazzák, ahol az aldimenziók pontszámának varianciáját vetik össze a közös faktorok által leírt varianciával. A hierarchikus omega együttható pedig azt fejezi ki, hogy az összpontszám varianciájának mekkora hányada magyarázható csak az általános faktorral (Fg), illetve az aldimenzió hierarchikus omega mutatójának kiszámításakor az aldimenzió varianciáját csak a specifikus faktor varianciájával vetjük öszsze, úgy, hogy az általános faktor hatását kontrolláljuk.

A bifaktoros modell esetében egy általános faktort és további alfaktorokat különböztethetünk meg. A TAS-34 esetében azt láthatjuk, hogy az egydimenziós modell faktorsúlyai és a bifaktoros modell általános faktorának súlyai nem különböznek számottevően és viszonylag kiegyenlítettek, az értékek 0,43 és 0,79 között ingadoznak (3. táblázat). Ezzel szemben a bifaktoros modellnél kapott alfaktorok faktorsúlyai már jóval változatosabb képet mutatnak, és viszonylag kevés olyan tétel van, amelynek faktorsúlya az alfaktorok esetében is eléri a 0,4-es értéket.

A TAS-23 esetében hasonló mintázódást figyelhetünk meg, annyi különbséggel, hogy itt az alfaktorok faktorsúlyai kiegyensúlyozottabbak, azaz a faktorsúlyok értéke viszonylag szúk tartományban mozog (4. táblázat).

A 3. és 4. táblázatok utolsó soraiban a dimenzió belső megbízhatóságát jelző mutatókat és az általuk magyarázott varianciát szemléltetjük. Mind a Cronbach-alfa, mind az omega megbízhatósági mutatók elfogadható reliabilitásokat jeleznek, csupán egyetlen dimenziónál, a TAS-34 ötödik faktoránál, az Emlékek élénksége dimenziónál láthatunk 0,75 alatti értékeket. Bár a fenti eredmény nagyon meggyőző, ugyanakkor, ha a hierarchikus 
omega és a magyarázott variancia mutatókat vizsgáljuk, akkor azt láthatjuk, hogy az aldimenziók megbízhatóságai messze elmaradnak az elfogadhatóság kritériumától, az aldimenziók által magyarázott variancia pedig csekély, mindössze 1-7\%. Érdemes megjegyeznünk, hogy a hierarchikus omega mutatónak nincs széles körben elfogadott határértéke, általában a 0,50-et tekintik a szükséges minimumnak, de sokkal inkább a 0,75-höz közel eső értékek elfogadását javasolják (Reise, Bonifay, \& Haviland, 2013).

A 3-4. táblázatban a(z általános és speciális) faktorok által magyarázott közös varianciát (Explained Common Variance: ECV) és az egyes tételekre adott válaszok és általános faktor közös varianciahányadát (Individual Explained Common Variance: IECV) is szemléltetjük (a táblázatok utolsó sorai és oszlopai). Mindezek mellett kiszámoltuk a tisztán egydimenziós modell által magyarázott varianciahányadot (Percent of Uncontaminated Correlations: PUC) is, amely az általános faktor által magyarázott varianciahányadot ragadja meg, de más módon, mint az ECV.${ }^{11}$ Bár a fenti mutatóknak nincs széles körben elfogadott határértéke, Rodriguez, Reise és Haviland (2016) úgy tartják, hogy a 0,70-nél magasabb ECV és PUC mutatók az egydimenziós modell érvényességét támasztják alá. Reise és munkatársai (2013) érvelése szerint pedig, ha a PUC mutató kisebb, mint 0,80; az általános faktor által magyarázott ECV mutató nagyobb, mint 0,60; és az általános faktor hierarchikus omega együtthatója nagyobb, mint 0,70, akkor ezek az eredmények valamilyen mértékú multidimenzionalitás jelenlétét támogatják, de ez még nem feltétlenül zárja ki azt, hogy a mérőeszközt elsődlegesen egydimenziósként értelmezzük. Az egyes tételek és az általános faktor közös varianciánál (IECV) általában a 0,80 vagy 0,85-nál nagyobb mutatók esetében tartják úgy, hogy a tétel egyértelmúen az általános látens dimenziót méri (Stucky \& Edelen, 2015).

A TAS-34 bifaktoros modelljénél a PUC értéke 0,85, az ECV értéke 0,80, az általános faktor hierarchikus omega együtthatója pedig 0,93. A 34 tételből 21 esetében (61,7\%) 0,80-nél magasabb IECV mutatókat látunk.

A 23 tételesre rövidített változatnál (TAS-23) a mutatók a következőképpen alakultak: PUC: 0,83; ECV: 0,75; az általános faktor hierarchikus omega együtthatója: 0,93. A 23 tételból 13 esetben (56,5\%) kaptunk 0,80-nél magasabb IECV mutatókat.

A fenti eredmények összességében a 34 tételes és a 23 tételes TAS egydimenziós modelljét támasztják alá, és hiába tudunk aldimenziókat megkülönböztetni a faktorelemzések segítségével, ezek magyarázott variancia-

11 Az elemzésekhez a Dueber (2017) által kidolgozott bifaktoros mutatók excel-alapú kalkulátorát használtuk. 
hányada az általános faktorhoz (Fg) képest elenyésző, a speciális faktorok megbízhatóságát jelző hierarchikus omega együtthatóval becsült belső megbízhatóságuk pedig csekély.

3. táblázat. A TAS-34 megerósító faktorelemzésének standardizált faktorsúlyai és az alfaktorok belső megbízhatósága

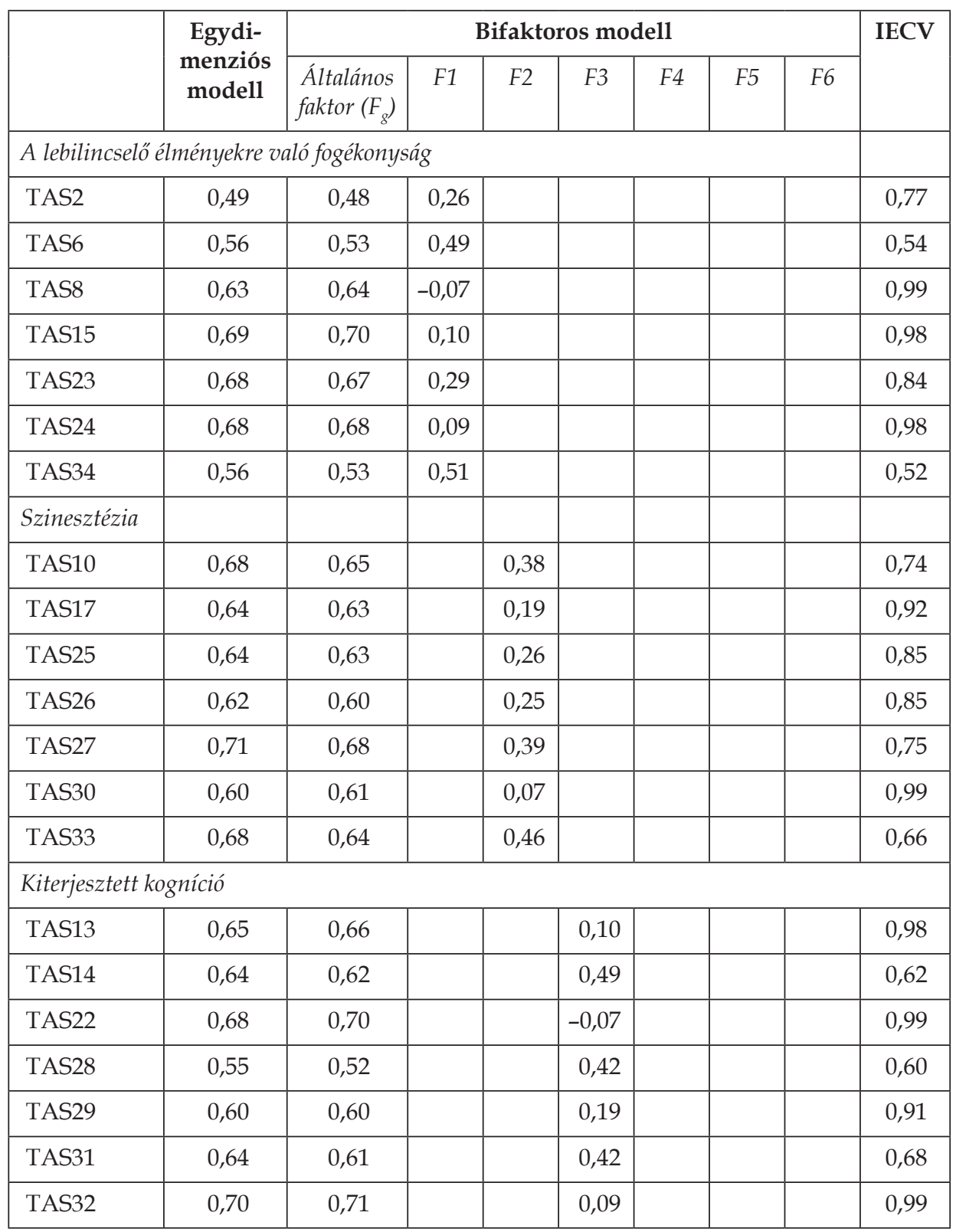




\begin{tabular}{|c|c|c|c|c|c|c|c|c|c|}
\hline & \multirow{2}{*}{$\begin{array}{c}\text { Egydi- } \\
\text { menziós } \\
\text { modell }\end{array}$} & \multicolumn{7}{|c|}{ Bifaktoros modell } & \multirow[t]{2}{*}{ IECV } \\
\hline & & $\begin{array}{l}\text { Általános } \\
\text { faktor }\left(F_{g}\right)\end{array}$ & $F 1$ & $F 2$ & F3 & $F 4$ & F5 & F6 & \\
\hline \multicolumn{10}{|c|}{ A tevékenységekben való teljes elmerülés } \\
\hline TAS3 & 0,53 & 0,49 & & & & 0,78 & & & 0,28 \\
\hline TAS7 & 0,62 & 0,62 & & & & 0,18 & & & 0,92 \\
\hline TAS12 & 0,58 & 0,58 & & & & 0,19 & & & 0,90 \\
\hline TAS16 & 0,78 & 0,79 & & & & 0,01 & & & 0,99 \\
\hline TAS18 & 0,56 & 0,56 & & & & 0,15 & & & 0,94 \\
\hline TAS21 & 0,57 & 0,56 & & & & 0,23 & & & 0,86 \\
\hline \multicolumn{10}{|c|}{ Az emlékek élénksége } \\
\hline TAS1 & 0,43 & 0,42 & & & & & 0,26 & & 0,72 \\
\hline TAS4 & 0,58 & 0,57 & & & & & 0,21 & & 0,88 \\
\hline TAS19 & 0,64 & 0,63 & & & & & 0,17 & & 0,93 \\
\hline \multicolumn{10}{|c|}{ Kiterjesztett tudatosság } \\
\hline TAS5 & 0,67 & 0,67 & & & & & & 0,22 & 0,90 \\
\hline TAS9 & 0,69 & 0,68 & & & & & & 0,34 & 0,80 \\
\hline TAS11 & 0,72 & 0,70 & & & & & & 0,49 & 0,67 \\
\hline TAS20 & 0,68 & 0,69 & & & & & & $-0,01$ & 0,99 \\
\hline $\begin{array}{l}\text { Cronbach- } \\
\text { alfa }\end{array}$ & 0,95 & 0,80 & 0,83 & 0,82 & 0,78 & 0,56 & 0,76 & & \\
\hline Omega & 0,96 & 0,85 & 0,87 & 0,86 & 0,83 & 0,61 & 0,83 & & \\
\hline $\begin{array}{l}\text { Hierarchikus } \\
\text { omega }\end{array}$ & 0,93 & 0,12 & 0,15 & 0,10 & 0,13 & 0,08 & 0,11 & & \\
\hline $\begin{array}{l}\text { Magyarázott } \\
\text { közös varian- } \\
\text { cia (ECV) }\end{array}$ & 0,80 & 0,04 & 0,04 & 0,04 & 0,05 & 0,01 & 0,02 & & \\
\hline
\end{tabular}


4. táblázat. A TAS-23 megerősítő faktorelemzésének standardizált faktorsúlyai és az alfaktorok belső megbízhatósága

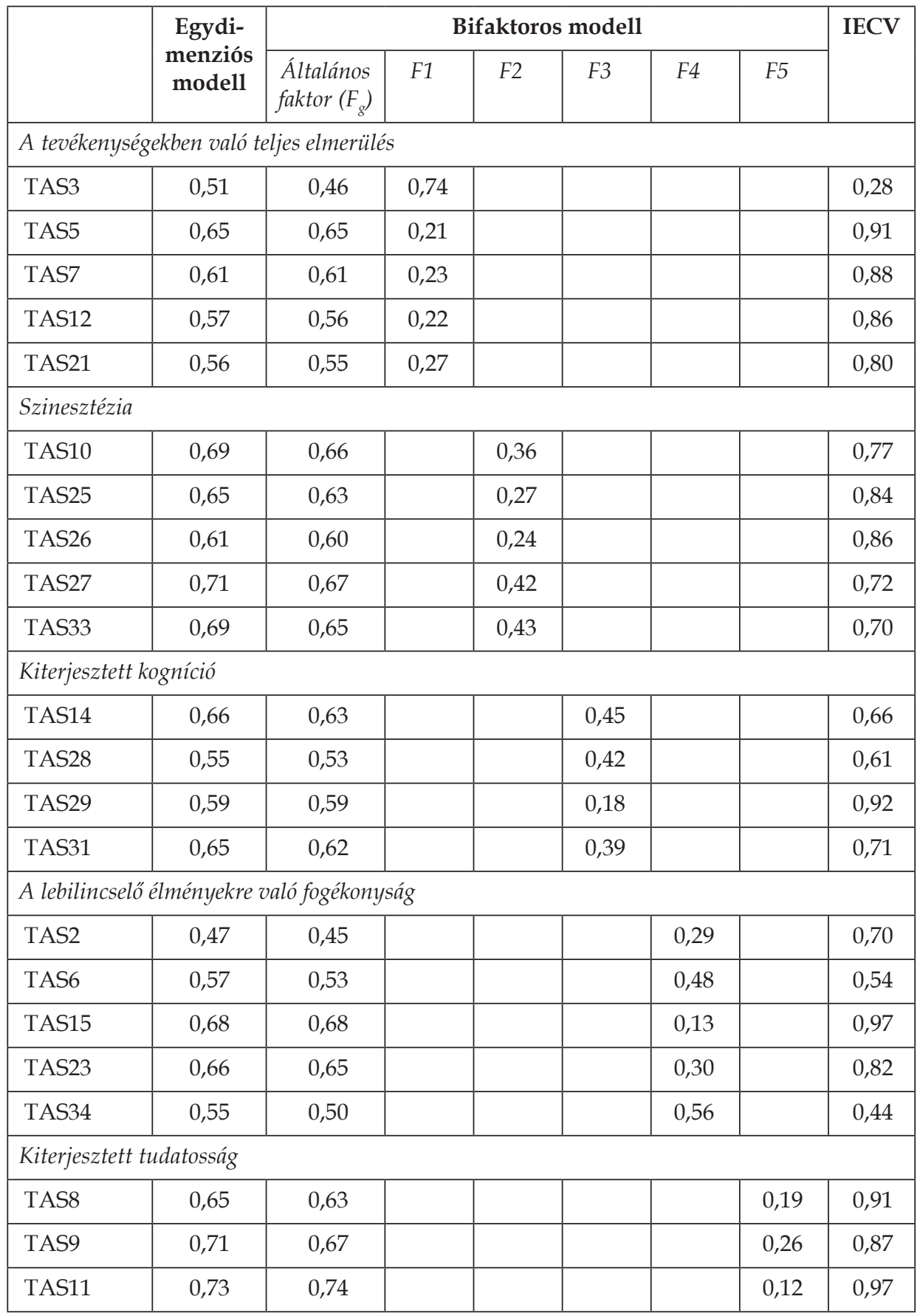




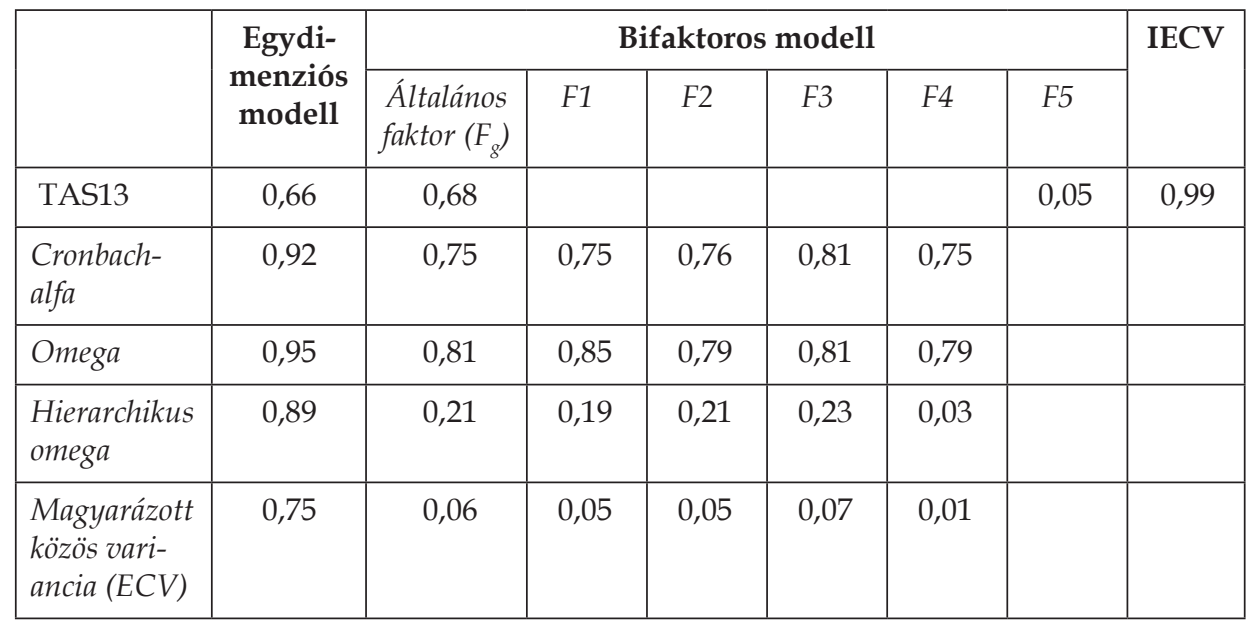

\subsubsection{Parallel-elemzés}

Az előzőekben a faktorok számának meghatározásához több szempontot is mérlegeltünk: pl. Scree-teszt, Kaiser-kritérium, varianciahányad, a dimenziók értelmezhetôsége. Bár a megerősítő faktorelemzések illeszkedési mutatói inkább egy bifaktoros elrendeződést támasztottak alá, ennek ellenére az aldimenziók alkalmazhatósága (a magyarázott varianciahányad és a belső megbízhatóság miatt) megkérdőjelezhető. Mivel a faktorok számának pontos megválasztása a jelen esetben kulcsfontosságú tényező, így az alábbiakban bemutatunk egy olyan módszert is, ami megbízhatóbb és objektív választ ad a faktorok számának meghatározásakor.

A Horn (1965) által bevezetett parallel-elemzés egy olyan szimulációs módszer, amely lehetőséget ad arra, hogy csak a szignifikáns főkomponenseket tartsuk meg. Az eljárás az eredeti vizsgálati minta fő paraméterei alapján (pl. mintaelemszám, változók száma) véletlenszerú mintákat képez, nem korreláló változókkal, és az így kapott sajátértékeket veti össze a vizsgálati korrelációs mátrix alapján kapott sajátértékekkel. Csak azokat a dimenziókat tartjuk szignifikánsnak, amelyek sajátértéke nagyobb, mint a random, korrelálatlan változókból képzett sajátérték. A módszer elve tehát az, hogy a mintabeli variabilitás véletlenszerúen is eredményezhet 1-nél nagyobb sajátértékú komponenseket, még akkor is, ha a változóink valójában nem korrelálnak, és nincs a változók varianciáját megragadó látens dimenzió. Bár a parallel-elemzés a komponens számok megállapításának jóval biztosabb módszere, mint a hagyományos módszerek (pl. Scree-teszt, Kaiser-kritérium, varianciahányad módszer), ennek ellenére kevesen alkalmazzák, mivel a társadalomtudományi kutatásokban leginkább elterjedt statisz- 
tikai programokba (pl. SPSS) rendszerint nincs beépítve. ${ }^{12}$ A véletlenszámsorozatok generálásán alapuló Monte-Carlo-módszerek komoly hátránya, hogy számítógépes futtatásuk igen időigényes. A jelen elemzések során a közel 1000 fős minta és 34 változó alapján képzett 500 véletlenszerúen generált korrelációs mátrixot a számítógép mintegy 80 perc alatt dolgozta fel.

A korábbi feltáró faktorelemzésre kiválasztott mintánkat $(n=951)$ parallel-elemzés segítségével is feldolgoztuk. Az 5-fokozatú Likert-skálás válaszformátumból származó változóink esetében a normalitás többnél is sérült, ezért az ilyen esetekben javasolt ún. polychoric korrelációt alkalmaztuk (Muthén \& Kaplan, 1985; 1992). Az elemzéseket a Lorenzo és Ferrando (2006; 2013) által kifejlesztett FACTOR ${ }^{13}$ elnevezésú számítógépes programmal készítettük el. A parallel-elemzés minimum rang faktorelemzési (Parallel Analysis using Minimum Rank Factor Analysis; MRFA) technikával és az előzőekben már említett 500 véletlenszerúen generált korrelációs mátrix segítségével történt (Timmerman \& Lorenzo-Seva, 2011). A valós adatmátrixunk első komponense az összvariancia 52,0\%-át magyarázta, a második és a harmadik komponensek pedig 5,5 és 4,9\%-ot. A véletlenszerúen és korrelálatlan változókból képzett mátrixok első komponense átlagosan 7,8, a második 7,4, míg a harmadik 7,1\%-ot magyarázott. Láthatjuk, hogy a valós adatok mátrixán nyert 52,0\%-os magyarázott variancia lényegesen meghaladja a véletlenszerúen kapott értéket $(7,8 \%)$, ezzel szemben a második vagy harmadik faktor $(5,5$ és 4,9) már nem magyaráz olyan mértékú varianciát, ami a véletlenszerúen szimulált eredményeket meghaladná, vagyis a 34 tétel egyetlen dimenzió köré csoportosítható.

\subsection{A TAS-34 dichotóm válaszformátumú változatának elemzése}

A TAS 34 tételes dichotóm válaszformátumú változatát a már korábban bemutatott elrendezésekhez hasonlóan (egydimenziós, korreláló faktor, másodlagos faktor, bifaktoros modell; 1. 1. ábra) egydimenziós és hatfaktoros

\footnotetext{
12 Érdemes megjegyeznünk, hogy az elmúlt években megjelenó módszertani közlemények (pl. Howard, 2015; Watkins, 2018; Izquierdo, Olea, \& Abad, 2014; Wood, Akloubou Gnonhosou, \& Bowling, 2015) a faktorok számának meghatározásakor már egyértelmúen a parallel-elemzést tekintik a legelfogadhatóbb módszernek, a hagyományos módszerek közül pedig a Kaiser-kritériumot már nem használják, csak más módszerekkel kiegészítve.

13 A program az alábbi internetcímről ingyenesen letölthető: http://psico.fcep.urv.es/utilitats/ factor/
} 
modellek segítségével vizsgáltuk. Csakúgy, mint az előzőekben most is robusztus becslési módszert, a súlyozott legkisebb négyzetes eljárás (Weighted Least Squares Mean and Variance Adjusted: WLSMV) módszerét alkalmaztuk, amely nem kívánja meg a változók normális eloszlását, és a kategorikus vagy ordinális kérdőív tételek elemzésének ajánlott módszere (Brown, 2006). ${ }^{14}$

Eredményeink szerint az illeszkedési mutatók minden tesztelt modell esetében elmaradnak az elvárt értéktől (5. táblázat), és jóval alacsonyabbak, mint Simor és munkatársainak (2011) elemzéseiben, vagy a TAS-34 5-fokozatú változatának esetében.

A hagyományos főkomponens-elemzés 10 egynél nagyobb sajátértékú komponenst eredményezett. Az első komponens az összvariancia 17,7\%-át magyarázta, a második 5,5\%-ot, harmadik 4,6\%-ot, míg a negyedik 4,3\%-ot magyarázott. A többi komponens magyarázó ereje $4 \%$ alatti volt. Mivel a fenti mutatókból szintén nagyon nehéz eldönteni a lehetséges dimenziók számát, ezért most is parallel-elemzést készítettünk az előzőekben már bemutatott technika segítségével.

A valós adatmátrixunk első komponense az összvariancia 28,7\%-át magyarázta, a második és a harmadik komponensek pedig 7,2 és 6,0\%-ot. ${ }^{15}$ A véletlenszerúen és korrelálatlan változókból képzett mátrixok első komponense átlagosan 7,3, a második 6,8, míg a harmadik 6,4\% -ot magyarázott. A valós adatok mátrixán nyert 28,7\%-os magyarázott variancia lényegesen meghaladja a véletlenszerúen kapott értéket (7,3\%), és a második dimenzióé is (7,2\% vs. 6,8\%). Ezzel szemben a harmadik faktor (6,0\% vs. 6,4\%) már nem magyaráz olyan mértékú varianciát, ami a véletlenszerúen szimulált eredményeket meghaladná.

Mivel a komponensek által magyarázott varianciák mértéke (főleg a másodiktól) kicsi, és az elvégzett feltáró faktorelemzés is sok olyan tételt eredményezett, amelyek egyetlen faktoron sem mutattak jelentős töltést $(<0,4)$, a tételek kommunalitás mutatói pedig sok esetben alacsonyak voltak $(<0,4)$, illetve a vizsgálati mintánk elemszáma $(n=399)$ is viszonylag alacsony, így az adatokat nem elemeztük tovább például egyes tételek elhagyásával. Láthattuk, hogy az egydimenziós modell nem adott megfelelő illeszkedési mu-

14 Fontos megjegyeznünk, hogy elemzéseinket más becslési módszerekkel is elvégeztük (pl. MLR, ULS), és ahol számottevő eltérést kaptunk azt jeleztük.

15 Ezek az értékek eltérnek a hagyományos elemzésnél kapott sajátértékektől, mivel a parallelelemzés során a dichotóm és ordinális válaszformátumú kérdőíves adatoknál ajánlott polychoric korrelációs mátrixot használtuk. 
tatójú eredményt, és a több (pl. 5-6) alfaktor létezését a modellilleszkedési mutatók nem támasztják alá, illetve azzal is számolnunk kell, hogy a dichotóm válaszformátum miatt a néhány tételból álló alskálák nagy valószínúséggel nem eredményeznének elfogadható belső megbízhatóságú skálákat.

5. táblázat. A TAS-34 dichotóm válaszformátumú kérdőív megerősítő faktorelemzésének illeszkedési mutatói

\begin{tabular}{|l|c|c|c|c|c|}
\hline \multicolumn{1}{|c|}{ Modell } & $\mathbf{X}^{\mathbf{2}}$ & $\mathbf{d f}$ & RMSEA & CFI & TLI \\
\hline egydimenziós & 738,22 & 527 & 0,050 & 0,828 & 0,817 \\
\hline hatfaktoros ferde & 690,72 & 512 & 0,047 & 0,854 & 0,840 \\
\hline másodlagos faktor & 702.99 & 521 & 0,047 & 0,852 & 0,840 \\
\hline bifaktoros & 646,10 & 494 & 0,044 & 0,876 & 0,859 \\
\hline
\end{tabular}

\section{Megbeszélés}

A kapott eredményeink összességében a TAS egydimenziós szerkezetét támasztják alá, amelynek hátterében nem csak az áll, hogy a dichotóm válaszlehetőségek nem biztosítanak annyi varianciát, hogy további megbízható alfaktorokat is megkülönböztessünk. Bár a 23 tételesre rövidített és ötfaktoros modellre változtatott bifaktoros TAS modell a megerősítő faktorelemzés és a Cronbach-alfa mutatók alapján jó mérőeszköznek bizonyult, ennek ellenére a részletesebb pszichometriai elemzések az alfaktorok belsó megbízhatóságát és alkalmazhatóságát megkérdőjelezik. Ennek alapján a TAS válaszformátumának 5-fokozatúra változtatása nem eredményezett látványos javulást a pszichometriai mutatók tekintetében, hiszen a 34 tételes dichotóm változat és az 5-fokozatú változat egydimenziós módszerként hasonló pszichometriai sajátosságokkal rendelkezik. Bár a dichotóm változat melletti tellegeni érvelését nem ismerjük, de feltételezhető, hogy hasonlóan az MMPI-hoz, amelynek fejlesztésében Tellegen szintén részt vett (Butcher, Graham, Tellegen, \& Kaemmer, 1989), az igaz - nem igaz válaszformátum mögött a könnyebb érthetőség és az értékelhetóség áll, amely alacsonyabb iskolai végzettségú személyeknél vagy klinikai betegpopuláción fontos szempont. Az 5-fokozatú Likert-skála alkalmazása mellett érvelők nemcsak a differenciáltabb értékelést, de a hagyományos statisztikai módszerekkel végzett elemezhetőséget is megemlítik (Jamieson, 2005; Leung, 2011). Bár számos tanulmány támasztja alá, hogy a többfokozatú Likert-skálák (pl. 5 vagy 7) sokkal érzékenyebbek, érvényességük és megbízhatóságuk jobb, mint a néhány fokozatból állóké (pl. Cummins \& Gullone, 2000; Leung, 
2011), ennek ellenére az empirikus eredmények szerteágazóak. ${ }^{16}$ Maga Likert (1932) a minél szélesebb tartományt felölelő értékelést javasolta, de akadnak olyan tanulmányok, amelyek arról számolnak be, hogy az 5- vagy 7-fokozatú válaszformátum esetében a mérőeszköz eléri a megbízhatóság felső határát, vagyis a skála belső konzisztenciája nem növekszik tovább (Finn, 1972; Jenkins \& Taber, 1977; Lissitz \& Green, 1975; Nunnally, 1978). Fontos módszertani kérdésként merül fel, hogy vajon a néhány fokozatból (pl. 3-5-7) álló Likert-skálás válaszformátumok mennyire tekinthetőek ordinális vagy intervallum-típusú változóknak, és mennyire elemezhetőek a hagyományos statisztikai módszerekkel: pl. tételeken végzett faktorelemzés, belső konzisztencia vizsgálat. Az ezzel kapcsolatos vizsgálati eredmények meglehetósen ellenmondásosak. Érdemes azonban kiemelnünk Waller és munkatársainak (1996) tanulmányát, amelyben a szerzők között Tellegen is szerepelt, és tanulmányukban amellett érvelnek, hogy a dichotóm vagy néhány fokozatból álló Likert-skálás válaszformátumok nem csak a normalitás sérülése miatt, hanem non-linearitás problémája miatt sem elemezhetők a hagyományos, lineáris becsléseken alapuló statisztikai módszerekkel. Tanulmányukban a Többdimenziós Személyiség Kérdőív (Multidimensional Personality Questionnaire; MPQ) Negatív Érzelmek Skálájának non-lineáris elemzésein keresztül mutatják be a megközelítés fontosságát, amely a tételek elemzésében és a kérdőív kimunkálásában alapvető jelentőségú. A tanulmány alapján feltételezhető, hogy az Abszorpció Skála elemzésénél és a tesztfejlesztés során szintén non-lineáris megközelítést tartanak leginkább elfogadhatónak. A tellegeni tesztfejlesztésról még azt is el kell mondanunk, hogy Wallerrel írt közös tanulmányukban (Tellegen \& Waller, 2008) kifejtik, hogy az MPQ kérdőív fejlesztését (amelynek része a TAS) externális szempontok vezérelték (pl. társjellemzések, klinikai diagnózis, egészségügyi leletek). Mint ahogy azt a bevezetóben is említettük az Abszorpció Skálánál hipnábilitásra való érzékenység jelentette a külső kritériumot. Az általuk kimunkált kritérium-alapú és exploratív tesztfejlesztést a külső kritériumok meghatározása, a tételek létrehozása és beválás elemzése, majd ugyanezen kör többszöri ismétlődése alkotta. A teljes

\footnotetext{
16 A témában megjelent közlemények eredményeinek változatosságát számos módszertani kérdés befolyásolja. Sok kutatás csak a skálák belső konzisztenciájának vizsgálatára fókuszál, és nem vesz figyelembe például más típusú reliabilitást (pl. teszt-reteszt vagy interrater), vagy a skála validitásának alakulását. Gyakori probléma, hogy az összehasonlító elemzéseket eltérő csoportokon felvett adatok alapján elemzik, és nem ismételt felméréseket készítenek, ahol ugyanaz a személy értékeli a tételeket eltérő válaszlehetőségek mentén. Ugyancsak módszertani problémaként merül fel, amikor páros és páratlan számú válaszlehetőségeket hasonlítanak össze: pl. 4- és 5-fokozatú Likert-skálák.
} 
MPQ kérdőív esetében összesen 1082 tétellel dolgoztak, amelyekből a végső változatban 276 tételt tartottak meg a 10 éves tesztfejlesztési folyamat során. A kérdőívnek összesen 7 változata volt, amíg a végleges változatot kialakították. Bár a tesztfejlesztési munka bizonyos szakaszában elemezték a mérőeszköz struktúráját, de nem törekedtek arra, hogy minél megbízhatóbb, magas belső konzisztenciával rendelkező skálákat hozzanak létre.

Elemzéseinknek több igen fontos módszertani implikációja is van. Elsőként azt emelhetjük ki, hogy a multidimenzionalitás megállapítására használt hagyományos módszereinknek (pl. Scree-teszt, Kaiser-kritérium, varianciahányad módszer) akadnak korlátai, mivel ezek meglehetősen szubjektívek. A jelen kutatás eredményei kiváló példát nyújtottak arra, hogy a lehetséges dimenziók számának objektív kritérium nélküli megállapítása könnyen vezethet téves eredményekhez és következtetésekhez. A tanulmányunkban bemutatott parallel-elemzés szükségességét a kapott eredmények ellenmondásossága indokolta, ami azt is jelzi, hogy a statisztikai módszerek megválasztása leginkább egy dinamikus folyamattal jellemezhetó, amelyben az eredmények befolyásolják a következőkben alkalmazott számítási eljárások megválasztását. Láthattuk, hogy a normalitás sérülése szintén lehet olyan szempont, amely alapján indokolttá válik a tervezettől eltéró becslési módszerek alkalmazása.

Az utóbbi időben számos olyan nemzetközi vagy hazai publikációval találkozhattunk, amelyben a tesztadaptáció vagy tesztfejlesztés folyamatában a strukturális érvényesség ellenőrzésére alkalmazott modellilleszkedési mutatókat minden másnál fontosabbként kezelik. A jelen vizsgálati eredményeink arra is kiváló bizonyítékul szolgálnak, hogy a modellilleszkedést nem tekinthetjük mindenek felettinek. Egy jobb illeszkedési mutatóval rendelkező modell, még nem feltétlenül jelzi azt, hogy egy mérőeszköz megbízhatósága, érvényessége vagy alkalmazhatósága jobb egy gyengébb illeszkedéssel rendelkező modellnél. A strukturális validitás csak egy a többi pszichometriai jellemzőből, amelyek mentén egy adott méróeszköz alkalmazhatóságát értékelhetjük. Itt fel kell hívnunk arra is a figyelmet, hogy a méróeszköz rövidítésekor is óvatosnak kell lennünk. Nem feltétlenül jó, ha a megfelelő belső konzisztencia vagy a megfelelő illeszkedési mutatók elérésének érdekében hagyunk el bizonyos tételeket. Általános gyakorlat, hogy a tesztadaptáció során a mérőeszköz illeszkedési mutatóit például úgy tesszük elfogadhatóvá, hogy a kevéssé illeszkedő negatívan megfogalmazott tételeket elhagyjuk, vagy csak azokat tartjuk meg, amelyek a dimenziók legnagyobb faktorsúlyú tételei. A tételek tartalmi elemzése nélkül így gyakran egy olyan ismétlődő és hasonló állításokat tartalmazó kérdéssort kapunk, amely bár jó illeszkedési mutatókkal rendelkezik, ennek ellenére a teszt érvényessége és a tételek tartalmi sokszínúsége csökken. 
A TAS 23 tételesre történő rövidítése kiváló példa arra is, hogy a belső konzisztencia becslésére széles körben alkalmazott Cronbach-alfa mutató komoly módszertani korlátokkal rendelkezik, és az alternatív mutatók alkalmazása (pl. hierarchikus omega együttható), illetve a korlátok hangsúlyozása a pszichológiai méréssel foglalkozó kutatók körében és az egyetemi oktatás szintjén szükségszerú.

Végezetül, de nem utolsó sorban azt is szeretnénk kiemelni, hogy a mérőeszközök hazai adaptációja során érdemes fokozottan ügyelni a méróeszköz szerzőjogi státuszára. A Tellegen Abszorpciós Skála részletes szakirodalmi keresése kapcsán szembesültünk azzal, hogy a University of Minnesota Press a skálát szerzőjogilag levédte, és bár ad engedélyt a kutatási célú felhasználásra, a tételek változtatásához és új skálák vagy alskálák létrehozásához nem járul hozzá. Bár az elemzéseink kezdetén, a tesztforgalmazó korlátozását még nem ismerve célunk volt, hogy megbízhatóbb és jobb pszichometriai tulajdonságokkal rendelkező kérdőívet fejlesszünk, a későbbiekben ezt már elvetettük. Mivel azonban a kapott eredményeink több fontos módszertani problémára hívják fel a figyelmet, így az elemzési eredményeinket edukatív célból részletesen bemutatjuk, még akkor is, ha ezek új skálák létrehozását célozták, amelyek azonban nem használhatóak fel a későbbi kutatások során.

\section{Köszönetnyilvánítás}

A vizsgálatok elvégzését az NKFI K-120334 számú pályázata támogatta.

\section{Szerzói munkamegosztás}

Rózsa Sándor: adatelemzési stratégia kialakítása, statisztikai elemzések, eredmények értelmezése, kézirat megszövegezése. Hupuczi Ernő: statisztikai elemzések. Martin László: adatgyuujtés és ellenőrzés. Birkás Béla: adatgyújtés és ellenőrzés. Hartung István: adatgyújtés és hipotézisalkotás. Hargitai Rita: adatgyújtés lefolytatása, a tanulmány szövegezése. Varga József: vizsgálat előkészítése, adatgyújtés. Láng András: konceptualizálás, adatgyújtés. Tiringer István: adatgyújtés és ellenőrzés. Kállai János: kutatási terv és kutatási hipotézisek kidolgozása, eredmények értelmezése, kézirat megszövegezése.

\section{Nyilatkozat érdekütközésról}

A szerzők ezúton kijelentik, hogy esetükben nem állnak fenn érdekütközések. 


\section{Irodalom}

Adorno, T.W., Frendkel-Brunswik, E., Levinson, D.J., \& Sanford, R.N. (1950). The authoritarian personality. New York: Harper \& Row

American Psychiatric Association. (2013). Personality disorders. In: Diagnostic and Statistical Manual of Mental Disorders (Fifth Edition ed.). Washington, DC: American Psychiatric Publishing Inc.

Anderson, J.C., \& Gerbing, D.W. (1984). The effect of sampling error on convergence, improper solutions, and goodness-of-fit indices for maximum likelihood confirmatory factoranalysis. Psychometrika, 49, 155-173.

Bachner-Melman, R., Dina, C., Zohar A.H., Constantini, N., Lerer, E., Hoch, S., et al. (2005) AVPR1a and SLC6A4 gene polymorphisms are associated with creative dance performance. PLoS Genet, 1(3), e42. Doi: 10.1371/journal.pgen.0010042

Bentler, P.M. (1990). Comparative fit indexes in structural models. Psychological Bulletin, $88,588-606$.

Bentler, P.M., \& Bonnet, D.C. (1980). Significance tests and goodness of fit in the analysis of covariance structures. Psychological Bulletin, 88(3), 588-606.

Bernstein, E.M., \& Putnam, F.W. (1986). Development, reliability, and validity of a dissociation scale. The Journal of Nervous and Mental Disease, 174(12), 727-35.

Brown, T. (2006). Confirmatory factor analysis for applied research. New York: Guildford

Browne, M.W., \& Cudeck, R. (1993). Alternative ways of assessing model fit. In K. A. Bollen \& J. S. Long (Eds.), Testing structural equation models (136-162). Newbury Park, CA: Sage

Butcher, J.N., Graham, J.R., Tellegen, A., \& Kaemmer, B. (1989). Manual for the restandardized Minnesota Multiphasic Personality Inventory: MMPI-2. Minneapolis: University of Minnesota Press

Cabrera-Nguyen, P. (2010). Author Guidelines for Reporting Scale Development and Validation Results. Journal of the Society for Social Work and Research, 1(2), 99-103.

Campbell, J.D., Trapnell, P.D., Heine, S.J., Katz, I.M., Lavallee, L.F., \& Lehman, D.R. (1996). Self-concept Clarity: Measurement, personality correlates, and cultural boundaries. Journal of Personality and Social Psychology, 70(1), 141-156.

Carleton, R.N., Abrams, M.A., \& Asmundson, G.J.G. (2010). The attentional resources allocation scale (ARAS): psychometric properties of a composite measure for dissociation and absorption. Depression and Anxiety, 27, 775-786.

Cho, E. (2016). Making Reliability Reliable: A Systematic Approach to Reliability Coefficients. Organizational Research Methods, 1-32.

Chou, C., \& Bentler, P.M. (1995). Estimates and tests in structural equation modeling. In R. H. Hoyle (Ed.), Structural equation modeling: Concepts, issues, and applications (37-55). Thousand Oaks, CA: Sage

Cicero, D.C., Becker, T.M., Martin, E.A., Docherty, A.R., \& Kerns, J.G. (2013). The role of aberrant salience and self-concept clarity in psychotic-like experiences. Personality Disorders, 4, 33-42.

Coan, R.W (1972). Measurable components of openness to experience. Journal of Consulting and Clinical Psychology, 39, 346.

Cohen, A.S., Matthews, R.A., Najolia, G.M., \& Brown, L.A. (2010). Toward a more psychometrically sound brief measure of schizotypal traits: introducing the SPQ-Brief Revised. Journal of Personality Disorders, 24(4), 516-537.

Cole, D.A. (1987). Utility of confirmatory factor analysis in test validation research. Journal of Consulting and Clinical Psychology, 55, 584-594. 
Council, J.R., Kirsch, I., \& Hafner, L.P. (1986). Expectancy versus absorption in the prediction of hypnotic responding. Journal of Personality and Social Psychology, 50, 182-9.

Crawford, H.J. (1982). Hypnotizability, daydreaming styles, imagery vividness, and absorption: a multidimensional study. Journal of Personality and Social Psychology, 42(5), 915-26.

Crowne, D., \& Marlowe, D. (1964). The approval motive: Studies in evaluative dependence. New York: Wiley

Cummins, R.A., \& Gullone, E. (2000). Why we should not use 5-point Likert scales: The case for subjective quality-of-life measurement. In Proceedings of the Second International Conference on Quality of Life in Cities (pp. 74-93). Kent Ridge, Singapore: National University of Singapore

Curran, P.J., West, S.G., \& Finch, J.F. (1996). The robustness of test statistics to nonnormality and specification error in confirmatory factor analysis. Psychological Methods, 1, 16-29.

Deacon, B., \& Abramowitz, J.S. (2006). Anxiety sensitivity and its dimensions across the anxiety disorders. Journal of Anxiety Disorders, 20, 837-857.

Digman, J.M. (1967). The procrustes class of factor-analytic transformations. Multivariate Behavioral Research, 2(1), 89-94.

Dueber, D.M. (2017). Bifactor Indices Calculator: A Microsoft Excel-based tool to calculate various indices relevant to bifactor CFA models. Letöltve: 2018. 08. 12-én: https:// doi. org/10.13023/edp.tool.01, illetve http://sites.education.uky.edu/apslab/ resources/

Dunn, T.J., Baguley, T., Brunsden, V. (2014). From alpha to omega: a practical solution to the pervasive problem of internal consistency estimation. British Journal of Psychology, 105(3), 399-412.

Eysenck, H.J. \& Eysenck, S.B.G. (1975). Manual of the Eysenck Personality Questionnaire. Hodder and Stoughton: London

Finn, R.H. (1972). Effect of some variations in rating scale characteristics on the means and reliabilities of ratings. Educational and Psychological Measurement, 34, 885-892.

Glisky, M.L., Tataryn, D.J., Tobias, B.A., Kihlstrom, J.F., \& McConkey, K.M. (1991). Absorption, openness to experience, and hypnotizability. Journal of Personality and Social Psychology, 60(2), 263-272.

Green, S.B., \& Yang, Y. (2009). Reliability of summed item scores using structural equation modeling: An alternative to coefficient alpha. Psychometrika, 74(1), 155-167.

Jenkins, G.D., Jr., \& Taber, T.D. (1977). A monte carlo study of factors affecting three indices of composite scale reliability. Journal of Applied Psychology, 62, 392-398.

Jöreskog, K. \& Sörbom, D. (1993). LISREL 8: Structural Equation Modeling with the SIMPLIS Command Language. Chicago, IL: Scientific Software International Inc.

Haan, N. (1977). Coping and defending. Processes of self environment organization. New York: Academic Press

Hartmann, E. (1991). Boundaries of the mind: A new psychology of personality. New York: Basic Books

Holmes, E.A., Brown, R.J., Mansell, W., Fearon, R.P., Hunter, E.C., Frasquilho, F., \& Oakley, D.A. (2005). Are there two qualitatively distinct forms of dissociation? A review and some clinical implication. Clinical Psychology Review, 25(1), 1-23.

Horn, J.L. (1965). A rationale and test for the number of factors in factor analysis. Psychometrika, 30, 179-185.

Horváth, B. (2016). Az abszorpció és a szexualitás összefüggései. Debreceni Egyetem. Pszichológiai Intézet. Múhelymunka. Letöltve: 2018. 07.11-én: https:/ / dea.lib.unideb.hu/dea/ handle/2437/226691 
Howard, M. (2015). A Review of Exploratory Factor Analysis (EFA) Decisions and Overview of Current Practices: What We Are Doing and How Can We Improve?, International Journal of Human-Computer Interaction, 32, 51-62.

Hu, L., \& Bentler, P.M. (1999). Cutoff criteria for fit indexes in covariance structure analysis: Conventional criteria versus new alternatives. Structural Equation Modeling, 6(1), 1-55.

IBM Corp. (2013). IBM SPSS Statistics for Windows, Version 22.0. Armonk, NY: IBM Corp. Izquierdo, I., Olea, J., \& Abad, F.J. (2014). Exploratory factor analysis in validation studies: Uses and recommendations. Psicothema, 26, 395-400.

Jamieson, G. A. (2005). The modified Tellegen Absorption Scale: A clearer window on the structure and meaning of absorption. Australian Journal of Clinical and Experimental Hypnosis, 2, 119-139.

Kane, N., Lind, E., Polasek, K.M., \& Hendric, J. (2017). Comparison of personality dispositions and benefic interferences in group of performing artists. International Journal of Music and Performing Arts, 5(1), 1-10.

Kerekes, Zs. (2012). A szorongás, mint adaptív viselkedés. A szorongásérzékenység mérésének tapasztalatai különböző csoportoknál. PhD Disszertáció, Pécs PTE BTK. Letöltve: 2018. 07. 10-én: https:/ / pea.lib.pte.hu/handle/pea/15215?show=full

Kihlstrom, J.F., Register, P.A., Hoyt, I.P., Albright, J.S., Grigorian, E.M., Heindel, W.C. (1989). Dispositional correlates of hypnosis: A phenomenological approach. International Journal of Clinical and Experimental Hypnosis, 37, 249-263.

Kihlstrom, J.F., Glisky, M.L., Peterson, M.A., Harvey, E.M., \& Rose, P.M. (1991).Vividness and control of mental imagery: A psychometric analysis. Journal of Mental imagery, 15, 133-142.

Kihlstrom, J.F. (2012). Tellegen Absorption Scale: Factors and content categories. Letöltve: 2018. 06. 14-én: http:// socrates.berkely.edu/ kihlstrom/TAS.htm

Kihlstrom, J.F. (2012). Searching for the self in mind and brain. Special Issue: What is the self? Social Cognition, 30, 367-379.

Kirsch, I. (1997). Suggestibility or hypnosis: What do our scales really measure? International Journal of Clinical and Experimental Hypnosis, 45(3), 212-225.

Koehn, S., Stavrou, N.A.M., Cogley, J., Morris, T., Mosek, E., Watt, A.P. (2017). Absorption in sport: A Cross-Validation Study. Frontiers in Psychology, 8, 1419.

Kulcsár, Zs., Rózsa, S., \& Reinhardt, M. (Szerk.), (2006). A poszttraumás növekedés feltételei. Trefort Kiadó

Laidlaw, T.,M., Dwivedi, P., Naito, A.,G., \& Gruzelier, J.,H. (2005). Low self-directedness (TCI), mood, schizotypy and hypnotic susceptibility. Personality and Individual Differences, 39(2), 469-480.

Larsen, R.J., Diener, E. \& Emmons, R.A. (1986). Affect intensity and reactions to daily life events. Journal of Personality and Social Psychology, 51, 803-814.

Lavallee, I.F., \& Campbell, J.D. (1995). Impact of personal goals on self-regulation processes elicited by daily negative events. Journal of Personality and Social psychology, 69, 341-352.

Leung, S. (2011). A Comparison of Psychometric Properties and Normality in 4-, 5-, 6-, and 11-Point Likert Scales. Journal of Social Service Research, 37(4), 412-421.

Likert, R. (1932). A technique for the measurement of attitudes. Archives of Psychology, 140, $5-53$.

Lissitz, R.W., \& Green, S.B. (1975). Effect of the number of scale points on reliability: A monte carlo approach. Journal of Applied Psychology, 60, 10-13.

Lorenzo-Seva, U., \& Ferrando, P.J. (2006). FACTOR: A computer program to fit the exploratory factor analysis model. Behavior Research Methods, 38(1), 88-91. 
Lorenzo-Seva, U., \& Ferrando, P.J. (2013). FACTOR 9.2 A Comprehensive Program for Fitting Exploratory and Semiconfirmatory Factor Analysis and IRT Models. Applied Psychological Measurement, 37(6), 497-498.

Lyons, L.C., \& Crawford, H.J. (1997). Sustained attentional and disattentional abilities and arousability: Factor analysis and relationships to hypnotic susceptibility. Personality and Individual Differences, 23(6), 1071-1084.

Marsh, H.W., Balla, J.R., \& McDonald, R.P. (1988). Goodness-of-fit indexes in confirmatory factoranalysis: The effects of sample size. Psychological Bulletin, 103, 305-312.

McCrae, R.R., \& Costa, P.T. (1985). Openness to Experience, in Perspectives in Personality, in Hogan, R., Jones, W. H. (eds.), JAI Press, Greenwich, Connecticut, 145-172.

McCrae, R.R., Zonderman, A.B., Costa, P.T., Jr., Bond, M.H., \& Paunonen, S.V. (1996). Evaluating replicability of factors in the Revised NEO Personality Inventory: Confirmatory factor analysis versus Procrustes rotation. Journal of Personality and Social Psychology, 70(3), 552-566.

McDonald, R. P. (1999). Test theory: A unified treatment. Mahwah, NJ: Lawrence Erlbaum

McIntosh, C. (2006). Rethinking fit assessment in structural equation modeling: A commentary and elaboration on Barrett (2007), Personality and Individual Differences, 42 (5), 859-67.

Muthén, B.O., \& Kaplan, D. (1985). A comparison of some methodologies for the factor analysis of nonnormal Likert variables. British Journal of Mathematical and Statistical Psychology, 38, 171-189.

Muthén, B.O., \& Kaplan, D. (1992). A comparison of some methodologies for the factor analysis of non-normal Likert variables: A note on the size of the model. British Journal of Mathematical and Statistical Psychology, 45, 19-30.

Muthén, L.K. \& Muthén, B.O. (1998-2017). Mplus User's Guide. Eighth Edition. Los Angeles, CA: Muthén \& Muthén

Nagy, F. (2016). Empátia és abszorpció vizsgálata a szerepjátékos szubkultúrában. Személyiségpszichológiai Múhelymunka. Pázmány Péter Katolikus Egyetem Bölcsészet- és Társadalomtudományi Kar. OTDK dolgozat. XXXIII. OTDK, Pedagógiai, Pszichológiai, Andragógiai és Könyvtártudományi Szekció, Személyiségpszichológia 2. tagozat. Letöltve: 2018. 11. 22-én: http:/ / otdt.hu/site/resume/43111

Nunnally, J.C. (1978). Psychometric theory. (2. ed). New York, NY: McGraw-Hill

Parsons, T.D., Barnett, M., \& Melugin, P.R. (2015). Assessment of personality and absorption for mediated environments in a college sample. Cyberpsychology, Behavior, and Social Networking, 18(12), 752-756.

Patrick, C.J., \& Kramer, M.D. (2017). Multidimensional Personality Questionnaire (MPQ). In V. Zeigler-Hill, T. Shackelford (Eds.), Encyclopedia of personality and individual differences. Cham: Springer

Pyszczynski, T., Greenberg, J., Solomon, S., Arndt, J., \& Schimel, J. (2004). Why do people need self-esteem? A theoretical and empirical review. Psychological Bulletin, 130(3), 435468.

Radtke, H.L., \& Stam, H.J. (1991). The Relationship between absorption, openness to experience, anhedonia, and susceptibility, International Journal of Clinical and Experimental Hypnosis, 39(1), 39-56.

Raine, A. (1991). The SPQ: A scale for the assessment of schizotypal personality based on DSMIII-R criteria. Schizophrenia Bulletin, 17(4), 555-564.

Reise, S.P., Bonifay, W.E., \& Haviland, M.G. (2013). Scoring and modeling psychological measures in the presence of multidimensionality. Journal of Personality Assessment, 95, 129-140. 
Rector, N.A., Szacun-Shimizu, K., \& Leybman, M. (2007). Anxiety sensitivity within the anxiety disorders: disorder-specific sensitivities and depression comorbidity. Behavioral Research and Therapy, 45, 1967-1975.

Reiss, S., Peterson, R.A., Gursky, D.M., \& McNally, R.J. (1986). Anxiety sensitivity, anxiety frequency, and the prediction of fearfulness. Behavior Research and Therapy, 42, 79-91.

Ritz, T., \& Dahme, B. (1995). Die Absorption-skala: konzeptuelle aspekte, psychometrische kennwerte und dimensionalität einer deutschsprachigen adaptation. Diagnostica, 41(1), 53-61.

Roche, S.M., \& McConkey, K.M. (1990). Absorption: Nature, assessment, and correlates. Journal of Personality and Social Psychology, 59(1), 91-101.

Rodriguez, A., Reise, S.P., \& Haviland, M.G. (2016). Evaluating bifactor models: Calculating and interpreting statistical indices. Psychological Methods, 21(2), 137-150.

Rosen, C., Jones, N., Chase, K.A., Melbourne, J.K., Grossman, L.S., \& Sharma, R.P. (2017). Immersion in altered experience: An investigation of the relationship between absorption and psychopathology. Consciousness and Cognition, 17(49), 215-226.

Rosenberg, M. (1965). Society and the adolescent self-image. Princeton, NJ: Princeton, University Press

Rózsa, S., Reinhardt, M., \& Kulcsár, Zs. (2006). A poszttraumás növekedés feltételeinek empirikus vizsgálata. In: Kulcsár, Zs., Rózsa, S., \& Reinhardt, M. (Szerk.) A poszttraumás növekedés feltételei és empirikus vizsgálata. Budapest: Trefort Kiadó

Sandstrom, G.M., \& Russo, F.A. (2013). Absorption in music: Development of a scale to identify individuals with strong emotional responses to music. Psychology of Music, 41(2), 216-228.

Sándor, F. (2017). A maladaptív nappali álmodozás vizsgálata átlagpopulációban. Debreceni Egyetem. Pszichológiai Intézet. Múhelymunka. Letöltve: 2018. 06. 22-én: https:/ / dea. lib.unideb.hu/dea/ handle/2437/241874

Sallay, V., Martos, T., Földvári, M., Szabó, T., \& Ittzés, A. (2014). A Rosenberg Önértékelési Skála (RSES-H): alternatív fordítás, strukturális invariancia és validitás. Mentálhigiéné és Pszichoszomatika, 15(3), 259-275.

Simor, P., Köteles, F., \& Bódizs, R. (2011). Elmerülés az élményben: A Tellegen-féle Abszorpció Skála vizsgálata egyetemista mintán. Mentálhigiéné és Pszichoszomatika, 12. 101-123.

Soffer-Dudek, N., Lassri, D., Soffer-Dudek, N., \& Shahar, G. (2015). Dissociative absorption: An empirically unique, clinically relevant, dissociative factor. Consciousness and Cognition, 36, 338-351.

Sowislo, J.F., \& Orth, U. (2013). Does low self-esteem predict depression and anxiety? A meta-analysis of longitudinal studies. Psychological Bulletin, 139, 213-240.

de Sousa, P., Sellwood, W., Spray, A., Fernyhough, C., \& Bentall, R.P. (2016). Inner Speech and Clarity of Self-Concept in Thought Disorder and Auditory-Verbal Hallucinations. The Journal of Nervous and Mental Disease, 204(12), 885-893.

Spielberger., D., Corsucrh., L., \& Lushenre., E. (1970). STAI: Manual for the State-Trait Anxiety Inventory (Self-Evaluation Questionnaire). Palo Alto, California: Consulting Psychologists Press

Steiger, J.H. (1990). Structural model evaluation and modification: An interval estimation approach. Multivariate Behavioral Research, 25(2), 173-180.

Stucky, B.D., \& Edelen, M.O. (2014). Using hierarchical IRT models to create unidimensional measures from multidimensional data. In S. P. Reise \& D. A. Revicki (Eds.), Handbook of item response theory modeling: Applications to typical performance assessment (183-206). London, UK: Taylor \& Francis 
Szabó, Cs. (1989). Szubjektív élmények különböző indukciós technikákkal létrehozott hipnózisokban. Doktori értekezés. Kossuth Lajos Tudományegyetem. Letöltve: 2018. 08. 13-án: http:/ / drszabocsaba.hu/index.php/11-sajat-munkakbol/23-letoeltheto-anyagok

Szabó, G.S. (2015). Az elvárások és a hanginger szerepe binaurális ütemek fenomenológiai hatásaiban. Doktori értekezés. Debreceni Egyetem. Letöltve: 2018. 07. 11-én: https://dea.lib. unideb.hu/dea/bitstream/handle/2437/209095/szabogergely_phd_t.pdf?sequence= 9\&isAllowed $=\mathrm{y}$

Székely. A., Kovács-Nagy, R., Bányai, É.I, Gősi-Gregus, C., Varga, K., Halmai, Zs., et al. (2010). Association between hypnotizability and the Catechol-o-Methyltransferase (COMT) polimorphism. International Journal of Clinical and Experimental Hypnosis, 58(3), 301-315.

Székely, P. (2016). A zenei bevonódás, mint személyiségvonás, kapcsolata az abszorpcióval, diszszociációval és a vizualitással. Debreceni Egyetem. Pszichológiai Intézet. Múhelymunka. Letöltve: 2018. 06. 12-én: https:/ / dea.lib.unideb.hu/dea/handle/2437/226270

Tanaka, J.S. (1993). Multifaceted conceptions of fit in structural equations models. In K.A. Bollen, J.S. Long (Ed), Testing structural equation models. (10-39). Newbury Park, CA: Sage

Tellegen, A. (1992). Note on structure and meaning of the MPQ Absorption Scale. Unpublished manuscript, University of Minnesota

Tellegen, A. \& Atkinson, G. (1974). Openness to absorbing and self-altering experiences („,absorption”), a trait related to hypnotic susceptibility. Journal of Abnormal Psychology, 83(3), 268-277.

Tellegen, A. (1982). Content categories: Absorption Items (Revised). Unpublished manuscript, University of Minnesota.

Tellegen, A. (1992). Note on structure and meaning of the MPQ Absorption Scale. Unpublished manuscript. Minneapolis MN: University of Minnesota

Tellegen, A., \& Waller, N.G. (2008). Exploring personality through test construction: Development of the Multidimensional Personality Questionnaire, In G.J. Boyle, G. Matthews, and D.H. Saklofske (eds.), Handbook of personality theory and testing: Vol. II. Personality measurement and assessment (pp. 261-292). Thousand Oaks, CA: Sage.

Tabachnick, B.G., \& Fidell, L.S. (2007). Using Multivariate Statistics (5th ed.). New York: Allyn and Bacon.

Taylor, S.E., \& Stanton, A.A. (2007). Coping resources, coping processes, and mental health. Annual Review of Clinical Psychology, 3, 377-401.

Timmerman, M.E., \& Lorenzo-Seva, U. (2011). Dimensionality Assessment of Ordered Polytomous Items with Parallel Analysis. Psychological Methods, 16, 209-220.

Tucker, L.R., \& Lewis, C. (1973). A reliability coefficient for maximum likelihood factor analysis. Psychometrika, 38(1), 1-10.

Waller, N.G., Tellegen, A., McDonald, R.P., \& Lykken, D.T. (1996). Exploring nonlinear models in personality assessment: Development and preliminary validation of a negative emotionality scale. Journal of Personality, 64(3), 545-576.

Van Prooijen, J.W., \& Van Der Kloot, W.A. (2001). Confirmatory analysis of exploratively obtained factor structures. Educational and Psychological Measurement, 61(5), 777-792.

Varga, K. (2004). A hipnotikus kapcsolat élményvilágának interakciós szemléletü elemzése. Habilitációs értekezés. Letöltve: 2010. 07. 27-én: http:/ / real-d.mtak.hu/839/1/dc_1059_15_ tezisek.pdf

Watkins, M.W. (2018). Exploratory Factor Analysis: A Guide to Best Practice. Journal of Black Psychology, 44(3) 219-246. 
Weitzenhoffer, A.M., \& Hilgard E.R. (1962) Stanford Hypnotic Susceptibility Scale Form C. Palo Alto, CA: Consulting Psychologists Press

Wild, T.C., Kuiken, D., \& Schopflocher, D. (1995). The role of absorption in experiential involvement. Journal of Personality and Social Psychology, 69(3), 569-579.

Wheaton, M.G., Deacon, B.J., McGrath, P.B., Berman, N.C., \& Abramowitz, J.S. (2012). Dimension of anxiety sensitivity in the disorders: Evaluation of the ASI-3. Journal of Anxiety Disorders, 26, 401-108.

Wheaton, B., Muthen, B., Alwin, D.F., \& Summers, G. (1977). Assessing reliability and stability in panel models, Sociological Methodology, 8(1), 84-136.

Wood, N.D., Akloubou Gnonhosou. D.C., Bowling, J. (2015). Combining Parallel and Exploratory Factor Analysis in Identifying Relationship Scales in Secondary Data. Marriage \& family review, 51(5), 385-395.

Worthington, R.L., \& Whittaker, T.A. (2006). Scale Development Research A Content Analysis and Recommendations for Best Practices. The Counseling Psychologist, 34, 806838.

Wylie, R.C. (1974). The self-concept. Revisited edition. Lincoln, Nebraska: University of Nebraska Press

Witthöft, M., Rist, F., \& Bailer, J. (2008). Evidence for a specific link between the personality trait of absorption and idiopathic environmental intolerance. Journal of Toxicology and Environmental Health, 71(11-12), 795-802.

Zinbarg, R.E., Barlow, D.H., \& Brown T.A. (1997). Hierarchical structure and general factor saturation of the anxiety sensitivity index: Evidence and implications. Psychological Assessment, 9(3). 277-294.

\title{
Psychometric properties of the Tellegen Absorption Scale
}

\author{
RÓZSA, SÁNDOR - HUPUCZI, ERNŐ - MARTIN, LÁSZLÓ - \\ BIRKÁS, BÉLA - HARTUNG, ISTVÁN - HARGITAI, RITA - VARGA, JÓZSEF \\ - LÁNG, ANDRÁS - TIRINGER, ISTVÁN - KÁLLAI, JÁNOS
}

Background: Absorption is most commonly measured by the 34-item Tellegen Absorption Scale (TAS). Despite the widespread use of TAS, relatively few studies focus on the detailed psychometric properties of the instrument (e.g. factor structure, internal consistency of subscales). Aims: Our study focus on the structure of absorption, to investigate the internal structure of the TAS (single latent dimension or multidimensional) and the reliability of the scale(s). We also investigated how the 5-point Likert scale and the dichotomous response formats affect the structural validity of the TAS and the internal homogeneity of its scales. Methods: A total of 1,935 students completed the Likert-type response format of TAS, and 399 the original dichotomous response format of TAS. The structures of the TAS was examined by confirmatory (e.g., single-factor model, model with second-order factor, bifactor model) and exploratory factor analysis and parallel-analysis. The internal consistencies were calculated not only in the conventional way (e.g. Cronbach-alpha) but also in the controlling of the general factor (hierarchical omega, explained common variance). Results: Across all three versions (original 34-item by 5-point Likert scale, and dichotomous response format, and brief 23-item TAS by 5-point Likert Scale format) results of bifactor analyses and model-based reliability estimates provided evidence for the 
calculation and interpretation of the total score as a measure of single latent dimension of absorption, but did not support the use of individual subscales. To determine the number of factors that can be applied, parallel-analysis provided a good estimation of the onedimensional structure of both the 5-point Likert scale and the dichotomous response format of TAS. Conclusions: Our results confirm that absorption can be considered as a single latent psychological variable and on the other hand it draws attention to the limitations of traditional statistical methods.

Keywords: absorption, Tellegen Absorption Scale (TAS), confirmatory and exploratory factor analysis, parallel-analysis, bifactor analysis, modelbased reliability, hierarchical omega 